\title{
Fossil snakes (Squamata, Serpentes) from the tar pits of Venezuela: taxonomic, palaeoenvironmental, and palaeobiogeographical implications for the North of South America during the Cenozoic/Quaternary boundary
}

\author{
Silvio Onary ${ }^{\text {Corresp.. }}{ }^{1}$, Ascanio D. Rincón ${ }^{2}$, Annie S. Hsiou ${ }^{1}$ \\ ${ }^{1}$ Departamento de Biologia, Laboratório de Paleontologia de Ribeirão Preto, Faculdade de Filosofia Ciências e Letras de Ribeirão Preto, Universidade de \\ São Paulo, Ribeirão Preto, São Paulo, Brazil \\ ${ }^{2}$ Centro de Ecología, Laboratório de Paleontología, Instituto Venezolano de Investigaciones Científicas, Caracas, Caracas, Venezuela \\ Corresponding Author: Silvio Onary \\ Email address: silvioonary@usp.br
}

Background. Tar seep deposits in South America historically are well-known for their rich record of fossil mammals, contrasting with only a few formal reports of reptile remains. Here we report a new snake fauna recovered from two tar pits from Venezuela. The fossil remains come from two localities: (a) El Breal de Orocual, which comprises an inactive tar seep estimated to be Plio/Pleistocene in age; and (b) Mene de Inciarte, an active surface asphalt deposit with an absolute age dating to the late Pleistocene. Methods. The taxonomic identity of all specimens was assessed via consultation of the relevant literature and comparison with extant specimens. The taxonomic assignments are supported by detailed anatomical description. Results. The Mene de Inciarte snake fauna comprises vertebral remains identified as the genus Epicrates sp. (Boidae), indeterminate viperids, and several isolated vertebrae attributable to "Colubridae" (Colubroidea, sensu Zaher et al. 2009). Amongst the vertebral assemblage at El Breal de Orocual, one specimen is assigned to the genus Corallus sp. (Boidae), another to cf. Micrurus (Elapidae), and several others to "Colubrids" (Colubroides, sensu Zaher et al. 2009) and the Viperidae family.

Conclusions. These new records provide valuable insight into the diversity of snakes in the north of South America during the Neogene/Quaternary boundary. The snake fauna of El Breal de Orocual and Mene de Inciarte demonstrates the presence of Boidae, Viperidae, "colubrids", and the oldest South American record of Elapidae. The presence of Corallus, Epicrates, and viperids corroborates the mosaic palaeoenvironmental conditions of El Breal de Orocual. The presence of Colubroides within both deposits sheds light on the palaeobiogeographical pattern of caenophidians snake colonization of South America and is consistent with the hypothesis of two episodes of dispersion of Colubroides to the continent. 
1 Fossil snakes (Squamata, Serpentes) from the tar pits of Venezuela:

2 taxonomic, palaeoenvironmental, and palaeobiogeographical

3 implications for the North of South America during the

4 Cenozoic/Quaternary boundary

5

6

\author{
Silvio Onary ${ }^{1}$, Ascanio D. Rincón ${ }^{2}$, and Annie S. Hsiou ${ }^{1}$
}

1. Departamento de Biologia, FFCLRP, Laboratório de Paleontologia, Universidade de São Paulo, Av. Bandeirantes 3900, 14040901, Ribeirão Preto, São Paulo, Brazil. 2. Laboratorio de Paleontología, Centro de Ecología, Instituto Venezolano de Investigaciones Científicas (IVIC), Carretera Panamericana Km 11, 1020-A, Caracas, Venezuela.

Corresponding author: Silvio Onary, silvioonary@usp.br

\begin{abstract}
Background. Tar seep deposits in South America historically are well-known for their rich record of fossil mammals, contrasting with only a few formal reports of reptile remains. Here we report a new snake fauna recovered from two tar pits from Venezuela. The fossil remains come from two localities: (a) El Breal de Orocual, which comprises an inactive tar seep estimated to be Plio/Pleistocene in age; and (b) Mene de Inciarte, an active surface asphalt deposit with an absolute age dating to the late Pleistocene.
\end{abstract}

Methods. The taxonomic identity of all specimens was assessed via consultation of the relevant literature and comparison with extant specimens. The taxonomic assignments are supported by detailed anatomical description.

Results. The Mene de Inciarte snake fauna comprises vertebral remains identified as the genus Epicrates sp. (Boidae), indeterminate viperids, and several isolated vertebrae attributable to "Colubridae" (Colubroidea, sensu Zaher et al. 2009). Amongst the vertebral assemblage at El Breal de Orocual, one specimen is assigned to the genus Corallus sp. (Boidae), another to cf. Micrurus (Elapidae), and several others to "Colubrids" (Colubroides, sensu Zaher et al. 2009) and the Viperidae family.

Conclusions. These new records provide valuable insight into the diversity of snakes in the north of South America during the Neogene/Quaternary boundary. The snake fauna of El Breal de Orocual and Mene de Inciarte demonstrates the presence of Boidae, Viperidae, "colubrids", and the oldest South American record of Elapidae. The presence of Corallus, Epicrates, and viperids corroborates the mosaic palaeoenvironmental conditions of El Breal de Orocual. The presence of Colubroides within both deposits sheds light on the palaeobiogeographical pattern of caenophidians snake colonization of South America and is consistent with the hypothesis of two episodes of dispersion of Colubroides to the continent. 


\section{INTRODUCTION}

45 Tar seeps represent a unique taphonomic and preservational context for the recovery of fossils, often providing unparalleled insight into the history of past biotas (LaDuke, 1991a;

47 Friscia et al., 2008; Solórzano, Rincón \& McDonald, 2015; Brown et al., 2017). These sites are generally interpreted as entrapment areas, with exemplar deposits, where were recovered mainly mammalian carnivore and associated herbivore taxa (Brown et al., 2017). Besides the representative mammalian fauna, these peculiar deposits also often yield small vertebrates, plants, and invertebrates (e.g. insects) in a lagerstätten-type condition (LaDuke, 1991a; Ward et al., 2005; Friscia et al., 2008; Rincón et al., 2009; Rincón, Prevosti \& Parra, 2011; Solórzano et al., 2015; Holden et al., 2015; Holden et al., 54 2017).

The Venezuela contains several tar pits, however, only two have been paleontologically explored: El Breal de Orocual (Czaplewski, Rincón \& Morgan 2005;

57 Rincón 2006; Rincón, White \& McDonald, 2008; Rincón et al., 2006, 2009; Rincón, 58 Prevosti \& Parra, 2011; Holanda \& Rincón, 2012) and Mene de Inciarte (Rincón et al., 59 2008; Prevosti \& Rincón 2007; Steadman, Oswald \& Rincón 2015). The majority of reports detailing the palaeodiversity of these deposits have focused on the large

61 mammals, e.g., canids, proboscids, felids, and xenarthrans (Prevosti \& Rincón, 2007;

62 Rincón et al., 2006, 2007, 2009; Rincón, Prevosti \& Parra, 2011; Holanda \& Rincón 2012;

63 Solórzano, Rincón \& McDonald, 2015), contrasting with relatively few reports of small 64 vertebrates and reptiles (Brochu \& Rincón 2004; Czaplewski, Rincón \& Morgan 2005; 
65 Fortier \& Rincón 2013; Steadman, Oswald \& Rincón 2015; Onary-Alves, Hsiou \& Rincón, 66 2016).

67 The interval recorded by these deposits covers key geological periods, 68 representing some of the major palaeobiogeographical and palaeoenvironmental 69 transitions within South America. The late Pliocene/ early Pleistocene (El Breal de 70 Orocual) is chronologically linked with the establishment of the continental connection 71 between the Central and South America continents (Iturralde Vinent \& MacPhee, 1999;

72 Coates et al., 2004) and thus the beginning of the Great American Biotic Interchange 73 (GABI) (Pascual, 2006; Woodburne, Cione \& Tonni, 2006). On the other hand, the late

74 Pleistocene (Mene de Inciarte) is well-known for the dramatic climatic changes that 75 occurred throughout the globe at this time (Peizhen, Molnar \& Downs, 2001). The 76 interaction between these factors shaped the palaeoenvironmental and 77 palaeobiogeographical histories of the groups inhabiting this region (Simpson, 1980; 78 Woodburne, Cione \& Tonni, 2006). However, most treatments of this history have been 79 strongly biased towards the mammalian fossil record (Simpson, 1980). In this 80 contribution, we report on the fossil snakes from two tar pits from Venezuela, discussing 81 their palaeobiogeographical and taxonomic implications. This partially fills a crucial gap 82 in the Pliocene fossil snake record, increasing our understanding of squamate diversity 83 during the Neogene/ Quaternary boundary in the North of South America.

\section{GEOLOGICAL SETTINGS}

\section{El Breal de Orocual}


87 The recovered fossil material comes from an inactive Tar seep deposit, located nearly 20

$88 \mathrm{~km}$ from Maturín County, Monagas state, north eastern Venezuela (Fig. 1). The locality is 89 situated within the Mesa Formation (Hackley et al., 2006; Rincón et al., 2009) and consists 90 of a series of open asphalt fissures, of which one has been extensively explored (ORS16 91 of Solórzano, Rincón \& McDonald, 2015; site of this study). The Tar pit has not been 92 dated absolutely; however, the Mesa Formation was estimated by thermoluminescence 93 (TL) to range from $\sim 2 \mathrm{Ma}$ to $0.5 \mathrm{Ma}$ (early to middle Pleistocene; Carbón, Schubert \& Vaz, 94 1992). Alternatively, the 30 identified taxa from the ORS16 vertebrate fossil assemblage 95 strongly suggests an age of late Pliocene-early Pleistocene, particularly with respect to 96 the occurrence of Smilodon gracilis (Carnivora, Felidae) and cf. Chapalmatherium 97 (Rodentia, Hydrochoeridae), which are considered characteristically 98 Pliocene/Pleistocene taxa (Rincón et al., 2009; Solórzano et al., 2015). Therefore, in this 99 contribution we follow the Plio-Pleistocene age ( 2.6 Ma) for the El Breal de Orocual 100 deposit, based on both biostratigraphy (Rincón et al., 2009; Rincón, Prevosti \& Parra, 101 2011; Holanda \& Rincón, 2012; Solórzano, Rincón \& McDonald, 2015) and geological 102 evidence that suggests an age of greater than 2.0 Ma for the Tar pit (see dating issues 103 discussed in Carbón, Schubert \& Vaz, 1992).

104

105

\section{Mene de Inciarte}

106 Mene de Inciarte is an active surface asphalt with production of consolidate sediments 107 and liquid oil (Steadman, Oswald \& Rincón, 2015). It is located in Mara County, Zulia 108 state, northwest of Venezuela, about $90 \mathrm{Km}$ from Maracaibo in the lower hills of Sierra de 109 Perijá (Fig. 1) (Czaplewski, Rincón \& Morgan, 2005; Rincón et al., 2008; Steadman, 
110 Oswald \& Rincón, 2015). Previous geochronological studies of the asphalt seep

111 estimated its formation during the Quaternary with reference to the flooding of fissures

112 with liquid asphalt (Urbani \& Galarraga, 1991) and relative dating based on the fossil

113 mammal record, the latter suggesting a Pleistocene age for the deposit (e.g.

114 pampatheriids, mastodons, equids, and ground sloths) (McDonald, Moody \& Rincón,

115 1999). A more recent absolute date yields an age estimate between $25,500 \pm 60014 \mathrm{C} \mathrm{yr}$

116 BP $(28,456-30,878$ cal yr BP $)$ and $27,980 \pm 37014 \mathrm{C}$ years BP $(31,165-32,843 \mathrm{cal}$ yr

117 BP), based on collagen samples of Glyptodon clavipes (Mammalia, Xenarthra) (Jull et al., 118 2004).

119

120 Fig 1: (Maps of the deposits)

121

122 MATERIAL \& METHODS

123 Specimens: All examined specimens consist of vertebral remains that are housed within 124 either the El Breal de Orocual (OR-) or Mene de Inciarte (MI-) collections of the 125 paleontological collection of Instituto Venezoelano de Investigacíones Científicas (IVIC), 126 Caracas, Venezuela. The fossils comprise precloacal trunk vertebrae and rarer 127 postcloacal specimens. The manner of preservation is variable between the specimens. 128

129 Anatomical analysis: To provide as accurate a taxonomic assignment as possible, all 130 material was described with reference to the relevant literature as well as comparison 131 with extant specimens outlined in Table 1. The anatomical description follows the 132 terminology of Auffenberg (1963); Hoffstetter \& Gasc (1967); Rage (1984, 2001); Lee \& 
133 Scanlon (2002); Hsiou \& Albino (2009); Albino (2011); Hsiou et al. (2014) (Fig.2A).

134 Quantitative data is based on LaDuke (1991a,b) (Fig. 2B). Measurements were taken 135 with an analogic calliper $(0.02 \mathrm{~mm})$ and are given in millimetres.

136

137 Fig 2: (A: Anatomical structures; B: Quantitative data)

138

139

Institutional abbreviations: AMNH, American Museum of Natural History, New York,

140 New York; MCN.D, Coleção Didática de Herpetologia, Museu de Ciências Naturais da

141 Fundação Zoobotânica do Rio Grande do Sul, Porto Alegre, Brazil; MCN-PV DR, Seção

142 de Paleontologia do Museu de Ciências Naturais da Fundação Zoobotânica do Rio

143 Grande do Sul, Coleção de Paleontologia de Vertebrados, Coleção Didática de Répteis,

144 Porto Alegre, Brazil; IVIC-OR, Instituto Venezoelano de Investigaciones Científicas EI

145 Breal de Orocual collection; IVIC-MI, Instituto Venezoelano de Investigaciones

146 Científicas Mene de Inciarte collection; UFMT, Coleção da Universidade Federal do Mato

147 Grosso, Mato Grosso, Brazil.

148

149 Table 1: Table of the comparative specimens consulted. Museum abbreviations are given 150 in the institutional abbreviations section.

151

152 RESULTS

153 SYSTEMATIC PALAEONTOLOGY

154 Serpentes Linnaeus, 1758

155 Alethinophidia Nopcsa, 1923 
156 Macrostomata Müller, 1831

157 Boidae Gray, 1825

158 Boinae Gray 1825

159 Corallus Daudin, 1803

160 Corallus sp.

161 Fig. 3

162

163 Referred material: An isolated posterior precloacal vertebra (IVIC OR-6113).

164 Locality and age: Tar Pit ORS16, El Breal de Orocual, Monagas State, Venezuela. Age

165 estimated to be late Pliocene-early Pleistocene based on the palaeofaunal assemblage 166 (Rincón et al., 2009; Rincón, Prevosti \& Parra, 2011; Solórzano, Rincón \& McDonald, 167 2015).

168 Description: The vertebra is dorsoventrally high, mediolaterally wide and 169 anteroposteriorly short, with its vertebral centrum smaller than the neural arch width (naw $170>\mathrm{cl})$. In anterior view, the zygosphene is thick and dorsoventrally inclined, being wider 171 than the cotyle $(z w>c t w)$. The prezygapophyseal articular facets are oriented parallel to 172 the horizontal plane. The prezygapophyseal process is short and extends beyond the 173 prezygapophyseal articular facet. The neural canal is subtriangular. The cotyle is circular, 174 with similar measurements of height and width (ctw cth). The paracotylar fossae are 175 deep and do not show evidence of paracotylar foramina. The paradiapophyses are 176 lateroventrally oriented, showing a clear distinction between the dia- and parapophyseal 177 articular facets. 
In posterior view, the lateral edges of the neural arch are characteristically vaulted.

179 Although the zygantrum is eroded, the probable zygantral foramen is nonetheless

180 observable as a deep excavation within the zygantral surface. Laterally to the zygantrum,

181 there is a series of small round pits filled with sediment, which here are interpreted as 182 parazygantral foramina (sensu Lee \& Scanlon, 2002). The postzygapophyses are 183 transversely level with the horizontal plane. The condyle has a marked circular outline 184 morphology (cnw cnh).

185 In lateral view, the neural spine rises from the anterior margin of the zygosphene 186 roof. It is anteroposteriorly short, exceeding from the posterior margin of the neural arch. 187 The zygosphene articular facets are oval and dorsolaterally oriented. Only a single lateral 188 foramen is observable on each side of the centrum. The vertebral centrum is 189 anteroposteriorly short with a well-marked precondylar constriction. The condyle, 190 although distorted, is convex and slightly deflected dorsally. Ventrally, the haemal keel 191 originates at the cotyle, extending posteroventrally until the level of the precondylar 192 constriction.

193 In ventral view, the centrum is anteroposteriorly short and triangular shaped. The 194 subcentral fossae are deep and well-delimited in the anterior region of the centra. The 195 postzygapohyses are broad and possesses subtriangular morphology.

196 In dorsal view, the neural arch is slightly wider than long (pr-pr>pr-po). The articular

197 facets of the prezygapophyses are anterolaterally oriented, subtriangular in shape, and 198 longer than wide (prl>prw). The zygosphene roof bears markedly triangular lateral lobes 199 with a distinct slightly convex mid lobe, typifying the crenate condition (sensu Auffenberg, 200 1963). A deep interzygapophyseal ridge extends between the pre- and 
201 postzygapophysis. There is a deep posterodorsal notch in the mid portion of the posterior 202 edge of the neural arch, which exposes a large part of the condyle.

203

204 Fig 3: (Corallus plate)

205

206 Measurements (in millimetres): IVIC OR-6113: cl. 3.4; coh.1.4; cow.1.3; cth. 0.9; 207 ctw.1.0; h. 5.7; naw. 3.6; nch. 1.4; ncw. 1.2; nsl. 2.3; nsh. 2.1; po-po. 5.3; pr-pr. 5.6; 208 pr-po. 4.7; prl. 1.6; prw. 1.0; zh. 0.9; zw. 2.9.

209

210 Identification and comparison: The specimen IVIC OR-6113 shares with Boidae the 211 following vertebral features: dorsoventrally broad and vaulted neural arch; a well212 developed and thick zygosphene; reduced prezygapophyseal process; high neural spine; 213 well-defined precondylar constriction; inclination of the prezygapophyses less than $15^{\circ}$; 214 vertebral centrum anteroposteriorly short; and presence of a haemal keel on midtrunk 215 vertebrae (Rage, 1984, 2001; Albino \& Carlini, 2008; Hsiou \& Albino, 2009; Hsiou et al., 216 2013).

217 Among Neotropical Boinae genera, IVIC OR-6113 can be distinguished from 218 Eunectes and Boa primarily with respect to its smaller absolute size (Hsiou \& Albino, 219 2010). Boa also differs substantially in its more vaulted condition with a deeper 220 posterodorsal notch (posterodorsal notch length $\sim 50 \%$ pr-po) (Onary-Alves, Hsiou \& 221 Rincón, 2016), whereas Eunectes displays a relatively depressed dorsoventrally neural 222 arch (Hsiou \& Albino, 2009). 
IVIC OR-6113 can be attributed to the genus Corallus based on the following

224 features: reduced absolute vertebral size (naw $<10 \mathrm{~mm}$ ); wide, broad, and vaulted neural

225 arch; prezygapophyses horizontally oriented $\left(\sim 180^{\circ}\right)$ in anterior view; crenate

226 morphology of the zygosphene roof in dorsal view; neural spine perpendicular to the

227 vertebral centrum; deep interzygapophyseal ridges; and the presence of small, pit-shaped

228 parazygantral foramina (sensu Lee \& Scanlon, 2002) (Teixeira, 2013).

229

With respect to intracolumnar variation, the specimen is consistent with the

230 morphology of posterior midtrunk vertebrae, as supported by the reduced vertebral

231 relative size ( $p r-p o<5 \mathrm{~mm}$ ); long haemal keel; deep subcentral fossae; very short vertebral

232 centrum; cotyle and condyle relatively circular shaped in outline; and a triangular shaped

233 parapophyseal facet (Teixeira, 2013).

234

IVIC OR-6113 shares with posterior precloacal midtrunk vertebrae of the

235 comparative specimens of Corallus (Table 1), the absolute vertebral size (pr-po $<5 \mathrm{~mm}$ );

236 its anteroposteriorly elongated proportions; and the perpendicular orientation of the neural

237 spine in relation to the vertebral centrum. In Boa the neural spine is oriented at a stronger

238 dorsoventrally angle in addition to possessing both a spinal blade and laminar crest

239 (sensu Albino, 2011). In contrast, Epicrates has high dorsoventrally neural spine

240 (Teixeira, 2013). The neural spine of Eunectes, despite being low as in Corallus, it is

241 markedly shortened anteroposteriorly (Hsiou \& Albino, 2009).

242 The zygosphene of IVIC OR-6113 is similar to the midtrunk vertebrae of Epicrates

243 and Corallus, which also exhibit a crenate morphology. In contrast, Boa and Eunectes

244 have a dorsoventrally thicker zygosphene, in addition to the presence of a median 
245 tubercle in Eunectes (Hsiou \& Albino, 2009) and a markedly concave zygosphene anterior 246 edge in Boa (Albino \& Carlini, 2008; Onary-Alves, Hsiou \& Rincón, 2016).

247 Finally, IVIC OR-6113 shares exclusively with Corallus horizontally oriented 248 prezygapophyseal facets, whereas in the other Neotropical boid genera these processes 249 are slightly-to-modestly inclined relative to the horizontal plane (Kluge, 1991; Rage, 2001; 250 Hsiou \& Albino, 2013; Teixeira, 2013; Onary-Alves, Hsiou \& Rincón, 2016).

251 There are eight extant species within the genus Corallus (Uetz \& Hošek 2016): C. 252 hortulanus (Linnaeus, 1758); C. caninus (Linnaeus, 1758); C. cookii (Gray, 1842); C. 253 batesi (Gray, 1860); C. annulatus (Cope, 1875); C. ruschenbergerii (Cope, 1875); C. 254 grenadensis (Barbour 1914); C. blombergi (Rendahl and Vestergren 1941), and C. 255 cropanii (Hoge, 1953). Among these species, three are currently found within Venezuela 256 (C. caninus; C. hortulanus; C. ruschenbergerii), with only C. ruschenbergerii present in 257 the area containing the fossiliferous deposit (Rivas et al., 2012). The lack of 258 autapomorphic features limits a species-level identification for IVIC OR-6113. However, 259 of the three species currently inhabiting the territory, C. caninus can be distinguished from 260 IVIC OR-6113 with respect to its greater absolute dorsoventrally vertebral height $(\mathrm{h})$; 261 presence of a median tubercle on the zygosphene. In general morphology, IVIC OR2626113 shares a close similarity with C. hortulanus and C. ruschenbergerii, however, we 263 conservatively prefer to restrict taxonomic assignment of the fossil specimen to Corallus 264 sp. for the time being.

265

266 Epicrates Wagler, 1830

267 Epicrates sp. 
268 Fig. 4

269

270 Referred material: An anterior isolated precloacal vertebra (IVIC MI-004)

271 Locality and Age: Mene de Inciarte Tar pit, Zulia state, Venezuela. Dated to $25,500 \pm 600$

$272{ }^{14} \mathrm{C}$ years BP $(28,456-30,878$ cal years BP $)$ and $27,980 \pm 370{ }^{14} \mathrm{C}$ years $\mathrm{BP}(31,165-$

27332,843 cal years AP), late Pleistocene (Jull et al., 2004).

274 Description: The vertebra is anteroposteriorly short, mediolaterally wide (naw $>\mathrm{cl}$ ), and

275 dorsoventrally high. In anterior view, the zygosphene dorsoventrally thick, with its articular

276 facets laterally oriented. The width of the zygosphene exceeds the width of the cotyle (zw

$277>\mathrm{ctw}$ ), with its median dorsal region present as a prominent convex border. The

278 prezygapophyses are oriented slightly dorsally above the horizontal axis of the centrum.

279 A small prezygapophyseal process is located below their articular facets. The neural

280 canal has a "trifoliate" morphology in cross-section with its width subequal to its height

281 (ncw nch). The cotyle is circular shaped in outline (ctw cth) and displays deep

282 paracotylar fossae but no paracotylar foramina. The paradiapophyses are broad and

283 show a clear distinction between the dia- and parapophyseal articular facets.

284

In posterior view, the neural arch is strongly vaulted. The median region of the

285 zyantrum is not preserved. The postzygapophyses of Ml-004 are slightly inclined upward.

286 The condyle is circular in shape (cow coh).

287 In lateral view, the neural spine is anteroposteriorly long, rising from the posterior 288 edge of the zygosphene. The articular facets of the zygosphene are oval shaped and 289 oriented dorsolaterally. The vertebral centrum of MI-004 is anteroposteriorly short and 290 delimited by a well-marked precondylar constriction. Below the precondylar constriction 
291 there is a long hypapophysis which extends to the edge of the precondylar constriction, 292 not exceeding beyond the posterior rim of the condyle.

293 In ventral view, the centrum has a marked triangular morphology tapering towards 294 the precondylar constriction. The specimen possesses two deep subcentral fossae, with 295 associated subcentral foramina excavating its interior on each side of the vertebra. A 296 narrow midline keel rises from the base of the cotyle and develops posteriorly into the 297 hypapophysis, however this process does not extend beyond the precondylar 298 constriction. The postzygapophyses are broad (pzw > pzl) and display a subtriangular 299 morphology. In dorsal view, the neural arch is slightly wider than long (pr-pr $>$ pr-po). The 301 articular facets of the prezygapophyses are subtriangular, anterolaterally oriented, and 302 longer than wide ( $\mathrm{prl}>\mathrm{prw}$ ). The anterior edge of the zygosphene roof is crenate (sensu 303 Auffenberg, 1963), bearing triangular lateral lobes and an anteriorly projected median 304 lobe. Paired parasagittal ridges (sensu Hsiou \& Albino, 2010) extend along the roof of the 305 neural arch from the posterior region of the zygosphene, nearly reaching the posterior 306 margin of the neural arch. A shallow interzygapophyseal ridge extends between the pre307 and postzygapophyses.

310 Fig 4: (Epicrates plate) 
312 Measurements (in millimetres): IVIC MI-004: cl:3.9; coh: 1.6; cow:2.3; cth:2.0;

313 ctw:2.1; h:9.6; naw:4.9; nch:1.6; ncw:1.9; nsl:3.0; nsh:2.0; po-po:6.8; pr-pr:7.1; pr314 po:5.1; prl:2.0; prw:1.4; zh:1.0; zw:3.6.

316 Identification and comparison: The specimen described above shares with the four 317 Neotropical boid genera the following features: anterior precloacal vertebrae that are 318 mediolaterally wide, dorsoventrally short, and dorsoventrally high relative to other aniliids 319 and macrostomatans families; a vaulted neural arch; vertebral centrum shorter than the 320 length of the neural arch; dorslolaterally inclination of the prezygapophysis articular facets 321 lower than $15^{\circ}$; presence of a short prezygapophyseal process; deep posterodorsal 322 notch; strong precondylar constriction; presence of paired subcentral foramina; and a 323 mediolaterally wide and dorsoventrally thick zygosphene (Rage, 2001; Lee \& Scanlon, 324 2002; Szyndlar \& Rage, 2003; Hsiou \& Albino, 2009).

IVIC MI-004 is attributed to the extant boid Epicrates based on the following 326 features: small absolute size of the vertebra $(h<10 \mathrm{~mm})$; vaulted neural arch; deep 327 paracotylar fossae; dorsoventrally high neural spine; hypapophysis which does not exceed the posterior margin of the condyle; crenate zygosphene; and a centrum with a strong triangular outline in ventral (Teixeira, 2013).

With respect to intracolumnar variation, the fossil is interpreted as an anterior 331 precloacal vertebra due to the presence of a well-developed hypapophysis, a feature 332 observed exclusively in this region of the axial skeleton of boids (Rage, 2001); and the 333 circular outline morphology of the cotyle and condyle (ctw cth) (Teixeira, 2013). 
The fossil is small in absolute size ( $\mathrm{h}<10 \mathrm{~mm}$ ), which is characteristic of the

335

336

337

338

339

340

341

342

vertebrae of boids like Corallus and Epicrates, being distinct from the comparatively great vertebral size of genera as Boa and Eunectes. The vertebral height (h) of IVIC MI-004, despite the broken apex of its neural spine, is proportionally greater (i.e. considering the ratio between the neural spine size and the centrum length) than in individuals of Corallus and Eunectes. In contrast to Boa, the neural spine of IVIC MI-004 is relatively lower, being more similar in general size to Epicrates. In posterior view, IVIC MI-004 exhibits a more convexly domed neural arch compared to anterior precloacal vertebrae of Eunectes and Corallus, which exhibit a more dorsoventrally depressed morphology.

Although broken, the neural spine of IVIC MI-004 is dorsoventrally high and mediolaterally long, contrasting with Corallus which bears a low and mediolaterally shortened neural spine (Hsiou \& Albino, 2009). The neural spine of Boa, in addition to bearing a well-delineated spinal crest and spinal blade (sensu Albino, 2011), exhibits a strong posterior orientation, both features that are absent in the fossil specimen.

IVIC MI-004 shares with Corallus and Epicrates the crenate morphology of the zygosphene roof (sensu Auffenberg, 1963); however, as pointed by Hsiou \& Albino (2010), this condition is variable with respect to both the individual and the position of the vertebra along the axial skeleton. Nonetheless, the crenate zygosphene of IVIC MI-004 does not resemble the well-developed concave morphology of the zygosphene roof seen in Boa, nor the condition present in Eunectes, which possesses a median tubercle between the neural canal and the zygosphene (Hsiou \& Albino, 2009).

Currently, two species of Epicrates are registered in Venezuela: E. cenchria, Linnaeus (1758) and E. maurus, Gray (1849), of which only the distribution of E. maurus 
357 encompasses the Mene de Inciarte site. No autapomorphic characters of the postcranial 358 elements have been identified as diagnostic to the specific level among the five 359 continental species of Epicrates (Rivera et al., 2011). We therefore maintain a 360 conservative approach and recognize IVIC MI-004 as Epicrates sp.

361 Caenophidia Hoffstetter, 1939

362 Endoglyptodonta Zaher et al., 2009

363 Colubroides Zaher et al., 2009

364 Colubroidea Oppel, 1811

365 Indeterminate genera and species

366 Fig. 5

367

368 Referred material: Four nearly complete precloacal vertebrae (IVIC OR-3667; IVIC OR369 6124; IVIC OR-2618; IVIC MI-005) and one postcloacal vertebra (IVIC OR-2917).

370 Localities and Age: IVIC OR-3667; IVIC OR-6124; IVIC OR-2618: Tar Pit ORS16, EI

371 Breal de Orocual, Monagas State, Venezuela. Estimated to be late Pliocene-early 372 Pleistocene in age based on the palaeofaunal assemblage (Rincón et al., 2009, Rincón, 373 Prevosti \& Parra, 2011; Solórzano, Rincón \& McDonald, 2015). IVIC MI-005: Mene de 374 Inciarte Tar pit, Zulia state, Venezuela. Dated to $25,500 \pm 600{ }^{14} \mathrm{C}$ years BP $(28,456-$ 37530,878 cal years BP) and $27,980 \pm 370{ }^{14} \mathrm{C}$ years $\mathrm{BP}(31,165-32,843$ cal years AP), late 376 Pleistocene (Jull et al., 2004).

377 Description: The fossils share the following common pattern: vertebrae with the length 378 of the vertebral centrum greater than the width of the neural arch (cl>naw). In anterior 379 view, the neural spine is dorsoventrally high and mediolaterally thin. The zygosphene of 
380 the specimens is dorsoventrally slender, with a convex dorsal edge. The neural canal is 381 subtriangular in shape with a tapering dorsal apex. Internally, three well-developed crests 382 extend anteroposteriorly towards the posterior margin of the neural canal. The 383 prezygapophyses vary in orientation among the specimens. IVIC OR-2618, IVIC OR3843667 , and IVIC MI-005 show a slight dorsolaterally inclination of the prezygapophyses 385 above the horizontal plane, whereas IVIC OR-6124 and IVIC OR-2917 exhibit a higher 386 dorsolaterally angle of inclination, reaching the mid portion of the neural canal. The the 387 prezygapophyses are well preserved in IVIC OR-3667 and IVIC OR-6124, the main body 388 of these processes are dorsoventrally elongate and extend well ventrally below their 389 articular facets. The cotyles of all vertebrae are rounded with subequal width to height 390 ratios (ctw cth). The paradiapophyses are anterolaterally oriented with a clear distinction 391 between the articular facets. The pleurapophyses of IVIC OR-2917 are dorsoventrally 392 long, mediolaterally slender, and strongly oriented ventrolaterally. The haemapophysis is 393 positioned ventral to the cotyle and are characterized by dorsoventrally thin processes 394 that extend a short distance along the sagittal axis of the element. In posterior view, the neural arches of all specimens are dorsoventrally depressed. 396 The zygantrum mediolaterally shortened and deep with some specimens (e.g., IVIC OR397 6124, IVIC OR-2618) exhibiting small paired zygantral foramina. The postzygapophyses 398 articular facets are variable in orientation: being inclined slightly dorsolaterally in IVIC 399 OR-3667, IVIC OR-6124, and IVIC OR-2917; horizontally oriented in IVIC MI-005; and 400 dorsoventrally oriented in IVIC OR-2618. The condyles of all specimens are circular in 401 outline, with a height similar or equal to the width (cow $\sim$ coh). 
402 In lateral view, the neural spine is dorsoventrally high, mediolaterally thin, and 403 anteroposteriorly elongated. Its rises from the posterior edge of the zygosphene, 404 extending until the posterodorsal notch. Paired lateral foramina are observable on each 405 side of the vertebral centrum only in IVIC OR-2917. The vertebral centra of all specimens 406 are anteroposteriorly elongated. The condyle is posterodorsally inclined. With the 407 exception of IVIC OR-2917, all specimens bear a well-developed haemal keel on ventral 408 surface of the centrum, which does not extend beyond the condyle.

409 In ventral view, a prominent haemal keel and haemapophysis (in IVIC OR-6124) 410 rise from the ventral border of the cotyle, extending longitudinally and reaching the 411 precondylar constriction. In IVIC OR-2618 and IVIC MI-005 paired subcentral foramina 412 can be observed on each side of the haemal keel. A marked subcentral groove excavates 413 the mid portion of the centrum of all specimens. The postzygapophyseal articular facets 414 are oval in shape and posterolaterally oriented in all specimens, except for IVIC MI-005 415 that shows a lateral orientation.

416 In dorsal view, the fossils are as wide mediolaterally as they are anteroventrally 417 long ( $\mathrm{pr}-\mathrm{pr} \sim \mathrm{pr}-\mathrm{po})$, except for IVIC OR-2618 which is wider than long ( $\mathrm{pr}-\mathrm{pr}>\mathrm{pr}-\mathrm{po})$. 418 The prezygapophyseal articular facets are oval shaped ( $\mathrm{prl}>\mathrm{prw}$ ) and anterolaterally 419 oriented. An anterolaterally oriented prezygapophyseal process rises ventrally to the the 420 articular facets. This process is particularly anterolaterally elongated in IVIC OR-3667.

421 The zygosphene roof is variable among the specimens, being concave in IVIC OR-3667, 422 straight in IVIC OR-6124, and crenate with a median lobe in IVIC MI-005 (sensu 423 Auffenberg, 1963). All specimens possess a mediolaterally thin neural spine, which 424 extends longitudinally until the posterior edge of the neural arch. The interzygapophyseal 
425 constriction is anteroposteriorly long, extending from the prezygapophyses to the articular 426 facets of the postzygapophyses. The posterodorsal notch of the neural arch is deep in all 427 specimens, exposing most of the cotyle.

428

429 Fig 5: (Colubroidea indet. plate)

430

431 Measurements (in millimetres): IVIC OR-3667: cl:6.5; coh:2.6; cow:3.0; cth:2.0; 432 ctw:2.5; naw:5.6; nch:2.6; ncw:3.0; nsl:5.1; nsh:1.9; pr-pr:9.0; prl:2.6; prw:2.1; zh:1.0; 433 zw:4.4.

434 IVIC OR-6124: cl:4.9; coh:1.7; cow:2.1; cth:1.4; ctw:2.1; h:5.0; naw:3.5; nch:1.4; 435 ncw:1.9; nsl:3.9; nsh:1.0; po-po:6.0; pr-pr:6.4; pr-po:6.6; prl:2.1; prw:1.1; zh:0.5; $436 \quad \mathbf{z w}: 3.0$.

437 IVIC OR-2618: cl:8.0; coh:3.1; cow:3.7; cth:3.1; ctw:3.1; naw:7.1; nch:2.1; ncw:3.1; 438 po-po:10.9; pr-pr:13.4; pr-po:11.0; prl:4.6; prw:2.4; zh:1.0; zw:5.0.

439 IVIC MI-005: cl:6.7; coh:2.5; cow:2.7; cth:2.0; ctw:2.2; h:7.1; naw:3.9; nch:2.0; 440 ncw:2.2; nsl:5.1; nsh:1.9; po-po:7.3; pr-po:8.0; prl:2.4; prw:1.3; zh:0.7; zw:3.8.

441 IVIC OR-2917: cl:9.4; coh:2.8: cow:3.6; cth:3.7; ctw:3.9; naw:5.2; po-po:9.8; pr442 pr:9.6; pr-po:11.7.

443

444 Identification and Comments: Colubroidea is a monophyletic group supported by 445 several synapomorphic features that includes both cranial and soft tissue characters; 446 however, none of them relate to the axial skeleton (Rieppel, 1988; Zaher, 1999; Zaher et 447 al., 2009). The group currently includes about 1853 of the 3596 catalogued extant snake 
448 species (Uetz \& Hošek, 2016), representing a well-diversified clade with a young 449 evolutionary history (i.e. Cenozoic). The fossils described above can be attributed to 450 Colubroidea based on the following combination of features: anteroposteriorly elongated 451 vertebral morphology; neural arch longer than wide ( $\mathrm{cl}>$ naw); extremely dorsoventrally 452 slender zygosphene $(\mathrm{zh} \leq 1 \mathrm{~mm})$; dorsoventrally high neural spine; paradiapophyses with 453 a clear distinction between their articular facets; and the presence of an anterolaterally 454 elongated prezygapophyseal process (Rage, 1984; Holman, 2000; Albino \& Montalvo, 455 2006).

456 Traditionally, vertebrae that display the above features have been attributed to the 457 generic group "Colubridae". However, "Colubridae" is considered paraphyletic, with most 458 previous analyses dealing with the group conducted using phenetic methods (Zaher, 459 1999) and therefore not representing a clade (i.e., a "natural" group) in the modern sense. 460 For this reason, we prefer to avoid assigning anything to this generic group.

461 Among Colubroidea, some families are well studied, such as Calamariidae, 462 Colubridae (clade sensu Zaher et al., 2009), Pseudoxenodontidae, Natricidae, and 463 Dipsadidae (sensu Zaher et al., 2009). However, none of these groups have diagnoses 464 pertaining to vertebral anatomy. It is worth noting, however, the variation in character 465 combinations among the individual fossils, suggesting the possible occurrence of at least 466 four different unidentified colubroidean taxa within the sample.

467

468 Endoglyptodonta Zaher et al., 2009

469 Viperidae Oppel, 1811

470 Indeterminate genera and species 


\section{Fig. 6}

472

473 Referred material: One almost complete precloacal vertebra (IVIC OR-2617); three 474 partial precloacal vertebrae (IVIC OR-6104; IVIC OR-1760; IVIC OR-3674); and a 475 fragment of vertebral centrum (IVIC OR-5544).

476 Locality and Age: Tar Pit ORS16, El Breal de Orocual, Monagas State, Venezuela. Age 477 estimated to be late Pliocene-early Pleistocene based on the palaeofaunal assemblage 478 (Rincón et al., 2009; Rincón, Prevosti \& Parra, 2011; Solórzano, Rincón \& McDonald, 479 2015).

480 Description: In general, the vertebrae are relatively dorsoventrally high (only observable 481 in IVIC OR-2617), slightly wider than long (pr-pr > pr-po) and have a centrum length 482 similar to the width of the neural arch (cl naw). In anterior view, the specimens bear a 483 dorsoventrally thin zygosphene with a straight dorsal margin. The articular facets of the 484 zygosphene are elliptical in outline and dorsally oriented. The neural canal is trifoliate with 485 a subequal width to length ratio (ncw nch). The articular facets of the anteroposteriorly 486 elongate prezygapophyses are dorsolaterally inclined relative to the horizontal plane at 487 an angle of $\sim 30^{\circ}$. The cotyles of all vertebrae are circular in outline, having a similar width 488 to height ratio (ctw cth). Deep paracotylar fossae excavate the laterally the cotyle. The 489 paradiapophyses, although eroded in some specimens, show a clear distinction between 490 the articular facets. The parapophyseal processes is small, anteroventrally oriented and 491 extend beyond the margin of the cotyle.

492 In posterior view (only preserved in IVIC OR-2617), the neural arch has a 493 triangular outline with a shallowly concave posterior surface. The zygantrum is 
494 mediolaterally wide and deep in depth. The postzygapophyses articular facets are 495 mediolaterally broad ( $p z w>p z l$ ) and inclined slightly dorsally. In all specimens the condyle 496 is circular in outline. A long dorsoventrally hypapophysis rises ventrally from the condyle, 497 exceeding its ventral margin.

Only IVIC OR-2617 preserves a neural spine. In lateral view it is well developed 499 and dorsoventrally high. The zygosphene articular facets of all specimens are oval and 500 dorsally oriented. The paradiapophyses are completely preserved only in IVIC OR-6104, 501 being dorsoventrally oriented. A large parapophyseal process is observable in the 502 anteroventral region of the parapophysis, being well developed and strongly oriented 503 anteroventrally. The centrum bears a prominent and anteroposterioly elongated 504 hypapophysis which in IVIC OR-2617 exceeds well beyond the posterior margin of the 505 condyle.

506 In ventral view, the vertebral centrum is mediolaterally narrow and 507 anteroposteriorly long. The subcentral fossae are variable in expression, being shallow in 508 some specimens (e.g. IVIC-6104, IVIC OR-1760), and deep in others (e.g. IVIC OR5092616 , IVIC OR-3674). In all specimens, the fossae are restricted to the anterior region of 510 the vertebral centrum. The subcentral fossae are delimited by a well-marked subcentral 511 margin. The hypapophysis develops longitudinally to the centrum, being broken in some 512 specimens but clearly surpassing the posterior margin of the condyle. The articular facets 513 of the postzygapophyses are anteroposteriorly long (pzl>pzw) and elliptical in outline.

514 In dorsal view, the anterior margin of the zygosphene in IVIC OR-2617 and IVIC 515 OR-6104 is concave, whereas IVIC OR-1760 and IVIC OR-3674 exhibit a straight 516 margin. The interzygapophyseal constriction is anteroposteriorly long and concave in 
517 shape. The neural spine of IVIC OR-2617) extends longitudinally along the dorsal

518 surface of the arch, terminating posterior to the posterior margin of the posterodorsal

519 notch. The prezygapophyseal articular facets are elongate ellipses ( $\mathrm{prl}>\mathrm{prw}$ ), and

520 oriented anterolaterally. The posterodorsal notch is deep, exposing a large portion of the

521 condyle (only preserved in IVIC OR-2617 and IVIC OR-3674).

522

523 Fig 6: (Viperidae indet. plate)

524

525 Measurements (in millimetres): IVIC OR-2617. cl:7.0; cth:2.1; ctw:2.3; h:15.4;

526 naw:6.0; nch:2.0; ncw:2.1; nsl:4.1; nsh:5.0; po-po:10.6; pr-pr:10.0; pr-po:8.0; prl:3.0;

527 prw:1.5; zh:1.0; zw:4.8. IVIC OR-6104. cl:5.8; cth:2.7; ctw:3.0; cth:2.1; ctw:2.6;

528 naw:5.5; nch:1.9; ncw:2.0; pr-pr:9.4; prl:2.3; prw:1.8; zh:0.8; zw:4.0. IVIC OR-3674.

529 cl:3.2; cth:1.1; ctw:1.1; coh:1.9; cow:1.6; naw:6.0; nch:3.5; po-po:5.1; pr-po:4.9;

530 prl:2.1; prw:1.1. IVIC OR-3674. cth:2.6; ctw:2.8; naw:6.8; nch:1.5; ncw:2.1; prl:2.5;

531 prw:2.8; zh:1.4.

532

533 Identification and Comments: The specimens share with Colubroidea the following 534 vertebral characters: gracile vertebrae which are longer than wide ( $\mathrm{pr}-\mathrm{po}>\mathrm{pr}-\mathrm{pr})$; 535 mediolatereally thin neural spine; dorsoventrally slender zygosphene; presence of 536 prominent accessory prezygapophyseal processes; and paradiapophyses with a clear 537 distinction between the dia- and parapophyseal articular facets (Rage 1984; Lee \& 538 Scanlon 2002; Albino \& Montalvo 2006). 
The specimens possess a well-developed hypapophysis, which is considered an

540 apomorphic character of "Xenodermatinae", Homalopsinae, "Pseudoxyrhophiinae",

541 "Boonodontinae", Elapidae, Viperidae, and Natricinae (Zaher, 1999). Among these

542 groups, IVIC OR-6104 shares with Viperidae a single autapomorphic postcranial

543 character: the presence of a well-developed, strongly anteroventrally oriented

544 parapophyseal process (Zaher, 1999; Zaher et al., 2009). Based on this character, IVIC

545 OR-6104 is unequivocally assigned to the Viperidae family. Despite the lack of the

546 parapophyseal process, the other specimens can be identified as Viperidae due to the

547 following combination of vertebral characters: a not well-elongated anteroposteriorly

548 vertebrae (e.g. compared to Colubridae clade sensu Zaher et al. 2009); slender and

549 straight zygosphene; well-developed hypapophyses; dorsoventrally depressed neural

550 arch; postzygapophyses processes strongly oriented anterolaterally; anteroposteriorly

551 short prezygapophyseal process; and subcentral fossae restricted to the anterior region

552 of the centrum (Auffenberg, 1963; Rage, 1984; Holman, 2000; Albino \& Montalvo, 2006;

553 Head, Sánchez-Villagra \& Aguilera, 2006; Hsiou \& Albino, 2011).

554 With respect to the taxonomic identity of the specimens, Albino \& Montalvo (2006)

555 do not recognize any diagnostic vertebral characters of Viperidae that are informative at

556 either a the generic or specific level. Among the most common studied genera, Camolez

557 \& Zaher (2010) reported subtle differences between Crotalus and Bothrops, mainly 558 regarding the morphology of the anterior margin of the zygosphene roof and the 559 orientation of the parapophyseal processes. Among these features, the anterior margin 560 of the zygosphene roof of Crotalus is generally strongly concave in its mid-region, a 561 condition observed in IVIC OR-2617 and IVIC OR-6104. 
562 Currently, six genera of Viperidae are distributed throughout Venezuela: Bothrops, 563 Crotalus, Bothriechis, Lachesis, and Porthidium, representing 12 valid species (Rivas et 564 al., 2012). Due to the lack of diagnostic vertebral features, as well the poor preservation 565 of the specimens, here we restrict assignment of the specimens to Viperidae indet. 566

567 Endoglyptodonta Zaher et al., 2009

568 Elapoidea Boie, 1827

569 Elapidae Boie, 1827

570 cf. Micrurus

571 Fig. 7

572

573 Referred material: One almost complete precloacal vertebra (IVIC OR-2619).

574 Locality and Age: Tar Pit ORS16, El Breal de Orocual, Monagas State, Venezuela. Age 575 estimated to be late Pliocene-early Pleistocene based on the palaeofaunal assemblage 576 (Rincón et al., 2009; Rincón, Prevosti \& Parra, 2011; Solórzano, Rincón \& McDonald, 577 2015).

578 Description: The vertebra is relatively anteroposteriorly elongate, with a centrum length 579 greater than the width of the neural arch (cl > naw). In anterior view, the zygosphene is 580 convex shaped, being dorsoventrally slender and mediolaterally wider than the cotyle (zw $581>\mathrm{ctw}$ ). The neural canal is trifoliate and as wide as it is high (ncw nch). The 582 prezygapophyses are short and oriented slightly above the horizontal plane. The only 583 preserved prezygapophyseal process is anteroposteriorly elongated and located ventral 584 to the right prezygapophysis. The cotyle is slightly flattened dorsoventrally such that the 
585 width is greater than the height (ctw > cth). The paradiapophyses show a clear distinction 586 between the dia- and parapophyseal articular facets.

587 In posterior view the neural arch is dorsoventrally depressed. The neural spine is 588 dorsoventrally low with its mid-region excavated by the posterodorsal notch to form a 589 deep sulcus. The postzygapophyses are oriented slightly lateroventrally. The condyle is 590 round with the height similar to its width (cow coh). The hypapophysis is dorsoventrally 591 shortened and located beneath the condyle, slightly exceeding its ventral margin.

592 In lateral view, the neural spine is very low, dorsally straight, anteroposteriorly 593 elongated, and sloping towards the posterior region of the neural arch. The articular facet 594 of the zygosphene is anterolaterally oriented and elliptical in shape. The paradiapophyses 595 exhibit a slight anterolateral orientation. The centrum is anteroposteriorly elongated and 596 displays a weakly developed precondylar constriction. Ventral to the centrum, the 597 hypapophysis is mediolaterally slender with a strong posterior orientation and, despite the 598 distal region not being preserved, probably extended beyond the posterior margin of the 599 condyle.

600 In ventral view, the centrum is long and narrow ( $\mathrm{cl}>$ naw), bearing shallow 601 subcentral fossae which are delimited by marked subcentral margins. The hypapophysis 602 extends longitudinally from the ventral margin of the cotyle to the mid region of the 603 centrum, not exceeding the posterior margin of the precondylar constriction. The 604 postzygapophyseal articular facets are elliptical in shape.

605 In dorsal view, the centrum has a width equal to its length ( $p r-p r=p r-p o)$. The 606 zygosphene roof possess anterolaterally tapering lateral edges and a non-crenate mid 607 region (i.e. straight anterior edge). The prezygapophyseal articular facets are elliptical in 
608 outline ( $\mathrm{prl}>\mathrm{prw}$ ) and orientated anterolaterally. A poorly preserved prezygapophyseal 609 process is located ventral to the right prezygapophyseal articular facet, being 610 mediolaterally elongate and transversely orientated relative to the prezygapophysis. 611 Located ventral to the prezygapophyses, the diapophyseal articular facets of the 612 paradiapophyses are convex in shape and lateroposteriorly oriented. The 613 interzygapophyseal constriction is anteroposteriorly long, extending from the base of the 614 prezygapophysis to the postzygapophysis, being relatively shallow. The neural spine is 615 mediolaterally thin, rising from the posterior region of the zygosphene roof and extending 616 Iongitudinally to contact the posterodorsal notch. The postzygapophyses articular facets 617 are slightly anterolaterally oriented.

618

619 Fig 7: (cf. Micrurus plate)

620

621 Measurements (in millimetres): IVIC OR-2619. cl:5.9; coh:2.0; cow:2.2; cth:1.6;

622 ctw:2.1; naw:3.6; nch:1.9; ncw:2.0; po-po:6.7; pr-pr:6.8; pr-po:6.8; prl:2.0; prw:0.9; 623 zh:0.7; zw:3.7.

624

625 Identification and Comments: Diagnostic features for Elapidae pertain mainly to cranial 626 characters (e.g. the morphology of the proteroglyph condition of the maxilla), in addition 627 to morphological traits associated with the venom glands (Underwood \& Kochva, 1993; 628 Zaher, 1999). No autapomorphic postcranial features have been reported at 629 genus/species level. Venezuela currently has two recognised genera of elapids: Micrurus 
630 and Leptomicrurus (Rivas et al., 2012), with two species of Micrurus previously reported

631 at the fossiliferous site: M. dissoleucus Cope, 1860 and M. isozonus Cope, 1860.

632 Among the comparative osteological material accessed for this study, IVIC OR-

6332619 shares with the genus Micrurus the following vertebral characters: gracile vertebrae

634 with a dorsoventrally depressed neural arch; oval shaped cotyle (ctw > cth);

635 anteroposteriorly elongated pre- and postzygapophyseal articular facets (prl, pzl > prw, $636 \mathrm{pzw})$; mediolaterally thin and very dorsoventrally low neural spine in lateral view, 637 possessing a straight dorsal edge that develops into a slope anteriorly to the posterior 638 margin of the neural arch; and thin hypapophysis which is strongly compressed 639 anteroposteriorly (Auffenberg, 1963; Holman, 1977). Due to the poor preservation of the

640 specimen, as well the lack of formal studies concerning the postcranial osteology of 641 Elapidae, here we prefer to restrict taxonomic attribution of IVIC OR-2619 to cf. Micrurus, 642 sharing an overall vertebral morphology with the modern genus, but lacking either 643 diagnostic or indicative traits that can be used for more precise assignment.

644

\section{DISCUSSION}

646 The Venezuelan snake fossil record is still scarce when compared to other South America

647 countries (e.g. Argentina, Brazil, Colombia). With respect to Cenozoic strata, the Socorro 648 Formation (middle Miocene) preserves Colombophis (Alethinophidia, incertae sedis), and 649 the boid Eunectes (Head, Sánchez-Villagra \& Aguilera, 2006 after Hsiou, Albino \& 650 Ferigolo, 2010; Hsiou \& Albino, 2010), whereas only Eunectes has been reported as 651 coming from the Urumaco Formation (middle Miocene), (Head, Sánchez-Villagra \& 652 Aguilera, 2006 after Hsiou \& Albino, 2010). Recently, Onary-Alves, Hsiou \& Rincón (2016) 
653 reported the presence of Boa constrictor from the El Breal de Orocual, representing the 654 single fossil snake record for that locality. The youngest record comes from the late 655 Pleistocene of the Cucuruchu gravels, where Head, Sánchez-Villagra \& Aguilera (2006) 656 identified an indeterminate Viperidae. Although fragmentary, such occurrences provide 657 direct insight into the palaeoenvironmental and palaeobiogeographic histories of snakes 658 during the Cenozoic/ Quaternary in South America.

659 The palaeoenvironmental conditions for the North of South America has primarily 660 been inferred with reference to the palaeofaunal mammal assemblage, which strongly 661 suggests the predominance of dry savanna crossed by fragmentary forests, rivers, and 662 patches of gallery forest comprised of humid-climate species of plants (Rincón et al., 663 2009; Rincón, Prevosti \& Parra, 2011; Solórzano, Rincón \& McDonald, 2015). The tar pit 664 snakes corroborate the interpretation of a mosaic environmental scenario composed of 665 small forests, arid regions, and rivers, analogous to the modern Venezuelan Llanos 666 (Rincón et al., 2007; Rincón et al., 2009; Rincón, Prevosti \& Parra, 2011). Although the 667 boid genera Corallus and Epicrates are currently widespread across South America 668 (Henderson, 1995), some species within these genera can persist only in suitable 669 microclimatic and microenvironmental conditions, particularly forest-exclusive species 670 (Rodrigues, 2005; Carvajal-Cogollo \& Urbina-Cardona, 2015). Most species of Corallus 671 and Epicrates require specific forested environments to establish a viable population 672 (Henderson et al., 1995), and a major change in the microclimate can threaten these 673 genera, even leading to local extinction (Rodrigues, 2005; Carvajal-Cogollo \& Urbina674 Cardona, 2015). The presence of Corallus in El Breal de Orocual, in addition to increasing 675 the known boid palaeodiversity, supports the existence of forest regions with adequate 
676 environmental conditions (i.e. humidity and temperature) for habitation by boids during

677 the Plio-Pleistocene. Moreover, the presence of Colubroides (sensu Zaher, 2009), such

678 as the "colubrids" (Colubroidea) and especially the viperids, corroborate the existence of

679 dry savanna components mixed with humid forested regions, since some colubrid and

680 viperid species inhabit open areas and are well-known to live in dry environments (e.g.

681 Crotalus sp.). Nowadays, Corallus and Epicrates are present in the Venezuelan Llanos

682 (Rivas et al., 2012), and the record of Corallus during the Plio/Pleistocene, together with

683 the presence of Epicrates in the Late Pleistocene, suggests that, despite climatic

684 fluctuations, the palaeoenvironment was amenable to habitation by, boids throughout this

685 time interval.

686 Regarding Colubroides (sensu Zaher et al., 2009), an interesting biogeographical

687 question pertains to the group's origins and entrance into South America (Fig. 8A-C).

688 Current palaeobiogeographical studies of the group suggest two episodes of dispersion

689 from North America to South America, the first dating back to the uplift of the Panama

690 Isthmus (Albino \& Montalvo, 2006; Hoffstetter, 1967; Cadle \& Greene, 1993; Albino,

691 1996b), with a second episode thought to have occurred during the Plio/Pleistocene

692 (Wüster et al., 2002, 2005; Head, Sánchez-Villagra \& Aguilera 2006). The oldest record

693 of "Colubridae" in the Americas come from the late Eocene of Georgia, North America

694 (Fig. 8A) (Parmley \& Holman, 2003), whereas the oldest South American occurrence

695 dates to the early Miocene of Argentina (Fig. 8B) (Albino, 1996b). This early Miocene

696 record, together with the late Miocene records of Viperidae from Argentina and

697 "Colubroids" from Brazil (Fig. 8B) (Verzi et al., 2004; Albino \& Montalvo 2006), suggests

698 that the first great dispersion of Colubroides occurred prior to major continental events 
699 such as the uplifting of the Panama Isthmus and the GABI (Albino \& Montalvo, 2006;

700 O'Dea et al., 2016). This dispersion can likely be explained via the aquatic crossing of a 701 series of island complexes within Central America during the Miocene (Fig. 8B) 702 (Hoffstetter, 1967; Cadle \& Greene, 1993; Albino, 1996b).

703 Based on the Venezuelan record of Viperidae in the late Pleistocene, Head, 704 Sánchez-Villagra \& Aguilera (2006) suggested that Colubroides could also have reached 705 South America during a later episode of the Neogene, mainly based on the Cucuruchu 706 gravels record. Indeed, the combination of the Colubroides specimens described here, 707 the fauna of Plio/Pleistocene "colubrids" and viperids at El Breal de Orocual, and the 708 presence of a suitable colonisation route after the complete uplift of the Panama Isthmus 709 (O'Dea et al., 2016), supports the hypothesis of a second entrance of Colubroides into 710 South America at the Pliocene/Pleistocene boundary (Fig. 8C). Additionally, studies in 711 the timing of molecular divergence (Wüster et al., 2002, 2005) suggest a similar pattern 712 in which viperids like Bothrops, Lachesis, and Bothriechis could have reached and 713 diversified in South America before the total closure of the Panama Isthmus (e.g. the early 714 Miocene records of Argentina, Albino, 1989; Albino, 1996b; Albino \& Montalvo, 2006). In 715 contrast genera such as Crotalus and Porthidium are thought to be late dispersers, only 716 reaching South America after the complete uplift of the Panama Isthmus (e.g. the 717 Venezuelan Plio/Pleistocene records of "colubrids" and viperids and the late Pleistocene 718 viperids; Head, Sánchez-Villagra \& Aguilera 2006 Fig. 8C). The viperid fossils of El Breal 719 de Orocual are geographically and chronologically consistent with this later estimated 720 entrance of Crotalus onto the continent (Wüster et al., 2002, 2005). With respect to the 721 described material, IVIC OR-6104 and IVIC OR-2617 bear no significant morphological 
722 distinction from extant comparative material of Crotalus (Table 1). These specimens

723 share with Crotalus the distinct characteristic of a concave anterior edge of the

724 zygosphene roof, which is argued to be exclusive to the genus (Camolez \& Zaher, 2010).

725 Despite the generic assignment of these Colubroides specimens, the material

726 nonetheless indicates great potential for future palaeobiogeographical investigations,

727 especially with respect to the history of viperids on the continent.

728 The extant species of "coral snakes" are currently represented in the Americas by

729 the genera Micruroides and Micrurus and in Asia by the genus Sinomicrurus (Lee et al.,

730 2016). Fossil remains of "coral-snakes" are very scarce and geologically young ( 16 to

$73113 \mathrm{Ma}$ ) (Holman, 1977). This is concordant with the time calibrated phylogeny of the

732 group, which estimates the divergence of the lineage at $\sim 30$ Ma. (Lee et al., 2016). South

733 American records are restricted to the Quaternary of Brazil and are represented by cranial

734 remains attributed to Micrurus corallinus and vertebrae assigned to Micrurus sp.

735 (Camolez \& Zaher, 2010). North America preserves the oldest fossil record of the group

736 from the late Barstovian North American Land Mammal Age of Nebraska (middle

737 Miocene) (Holman, 1977), whereas material attributed to Micrurus fulvius and Micrurus

738 cf. M. fulvius is known from the Pleistocene of Florida (Auffenberg, 1963). Records dating

739 to the middle Miocene of Europe demonstrate the presence of the extinct Micrurus

740 gallicus and Micrurus cf. M. gallicus, as well as indeterminate Micrurus vertebral material

741 (Rage \& Holman, 1984; Venczel, 2001; Ivanov \& Böhme, 2011). However, the

742 palaeobiogeographical history of the genus Micrurus is somewhat complex and the

743 scarcity of studies pertaining to axial skeleton anatomy hampers the identification of fossil

744 material to a specific level, preventing further inferences about the palaeobiological past 
745 of the group (Head, Mahlow \& Müller, 2016). Although this also impacts on our knowledge

746 of the palaeobiogeography of Micrurus, Rage \& Holman (1984), based on the fossil

747 record, inferred a North American origin of the genus, followed by an early Miocene

748 dispersion to Asia before eventually reaching Europe. The South American continent is

749 estimated to have been colonized by Micrurus following the complete uplift of the Panama

750 Isthmus ( 2.8 Ma.) (O’Dea et al., 2016), with dispersion potentially related to decreasing

751 average temperatures within the higher latitudes of North America (Rage \& Holman,

752 1984). The putative cf. Micrurus described herein is geographically and temporally

753 consistent with the hypothesis of a South American colonization of "coral-snakes" during

754 the Plio/Pleistocene (Fig. 8C) and represents an interesting addition to our current

755 understanding of the biogeography of the group.

756

\section{CONCLUSIONS}

758 The Venezuelan fossil snake record is becoming increasingly better understood, and this 759 report contributes to our knowledge of Cenozoic squamate fossils from South America as 760 a whole. The tar pit material described herein demonstrates the presence of several 761 snake groups, including Boidae, Viperidae, "colubrids", and the putative oldest South 762 American record of Elapidae. The presence of Corallus, Epicrates, and viperids, together 763 with the previously described Boa constrictor, further supports the mosaic nature of the 764 palaeoenvironment of El Breal de Orocual, being composed of forested areas together 765 with savannah and dry open areas. The presence of Colubroides (sensu Zaher et al. 766 2009), especially the occurrence of putative fossils of Crotalus and cf. Micurus, is 767 consistent with the hypothesis of a second episode of dispersion and colonization of the 
768 group into South America, following the total uplift of the Panama Isthmus. This material

769 therefore contributes genuine insight into specific palaeobiogeographic and

770 palaeoenvironmental patterns, representing an important preliminary step. However, only

771 identification to lower taxonomical levels can furnish more precise inferences regarding

772 the dispersion patterns of these snake groups into South America. In this sense, the

773 exhaustive anatomical analysis of postcranial material in addition to the application of new

774 methodologies, such as three-dimensional morphometrics, constitutes a crucial future

775 direction for research into this part of the palaeontological record.

776

\section{ACKNOWLEDGEMENTS}

778 We are deeply grateful to the following curators, staffs, and collection managers for the 779 access and support during the development of the research: CJ Raxworthy, D Kizirian, 780 FT Burbrink, MG Arnold, and L Vonnahme, of the Department of Herpetology (AMNH). 781 SO thanks the following researchers of the IVIC, D Ramoni, D Rauseo, M Quiroga782 Carmona, L Criollo, Y Reina, A Solórzano, M Flores, MFP Carillo, and E Catari for support 783 while undertaking work within Venezuela. We are much indebted to HA Blain (IPHES) 784 and J Scanlon (UNSW) for their valuable reviews, comments, language checking, and 785 suggestions that greatly improved our manuscript. We want to acknowledge BW McPhee 786 (FFCLRP/USP) for providing exceptional language and anatomical edits that sharply 787 improved our work. Lastly, the authors extend special gratitude to the reviewer Jean788 Claude Rage (in memoriam) (MNHN), whose insightful suggestions and expert 789 observations improved not just the quality of this contribution, but the field of 790 palaeoherpetology as a whole.

791

792

793

794

795 


\section{REFERENCES}

797 Albino AM, 1989. Primer registro de Colubroidea (Reptilia: Serpentes) de Argentina 798 (Edad Montehermosense s.l., Plioceno). Ameghiniana 25:281-287.

799

800

Albino AM. 1996a. The South America Fossil Squamata (Reptilia: Lepidosauria). 801 Münchner Geowissenschaftliche Abhandlungen Reihe A: Geologie und Paläontologie 30:185-202.

803

804

Albino AM. 1996b. Snakes from the Miocene of Patagonia (Argentina) Part II: the Colubroidea. Neues Jahrbuch für Geologie und Paläontologie, Abhandlungen 200: 353360 .

807

808

809

810

811

812

813

814

815

816

817

818

819

820

821

822

823

824

825

826

827

828

829

830

831

832

833

834

835

836

837

838

839

Albino AM, Carlini A. 2008. First record of Boa constrictor (Serpentes, Boidae) in the Quaternary of South America. Journal of Herpetology 42: 82-88.

Albino AM, Montalvo CL. 2006. Snakes from the Cerro Azul Formation (Upper Miocene), central Argentina, with a review of fossil viperids from South America. Journal of Vertebrate Paleontology 26: 581-587.

Albino AM. 2011. Morfologia vertebral de Boa constrictor (Serpentes: Boidae) y la validez del gênero mioceno Pseudoepicrates Auffenberg, 1923. Ameghiniana 48: 53-62.

Auffenberg W. 1963. The fossil snakes of Florida. Tulane Studies in Zoology 10: 131216.

Barbour T. 1914. A Contribution to the Zoögeography of the West Indies, with Especial Reference to Amphibians and Reptiles. Memoirs of the Museum of Comparative Zoölogy 44: 205-359.

Brochu CA, Rincón AD. 2004. A Gavialoid Crocodylian from the lower Miocene of Venezuela. Special Papers in Palaeontology 71: 61-79.

Brown C, Curd E, Anthony F. 2017. An actualistic experiment to determine skeletonization and disarticulation in the La Brea Tar Seeps. Palaios 32: 119-124.

Cadle JE, Greene HW. 1993. Phylogenetic patterns, biogeography and the ecological structure of Neotropical snake assemblages. In: R.E. Ricklefes, and D. Schluter (Eds), Species diversity in ecological communities. Historical and geographical perspectives. Chicago, University of Chicago Press, 281-293.

Camolez T., Zaher H. 2010. Levantamento, identificacão e descrição da fauna de Squamata do Quaternário Brasileiro (Lepidosauria). Arquivos de Zoologia, Museu de Zoologia da Universidade de São Paulo 41: 1-96. 
840 Carbón J, Schubert C, Vaz, JE. 1992. Caracterización y edades termoluminiscentes de 841 los sedimentos de la Formacion Mesa, en dos localidades del sur de Anzoategui 842 (Venezuela). Acta Científica Venezolana 43: 387-391.

843

844

845

Carvajal-Cogollo JE, Urbina-Cardona NU. 2015. Ecological grouping and edge effects in tropical dry forest: reptile-microenvironment relationships. Biodiversity \& Conservation 24: $1109-1130$

Cope ED. 1860. Supplement to "A catalogue of the venomous serpents in the Museum of the Academy of Natural Sciences of Philadelphia, with notes on the families, genera, and species.". Proceedings of the Academy of Natural Sciences of Philadelphia 1860: 7274.

Cope ED. 1875. On the Batrachia and Reptilia of Costa Rica with notes on the 854 herpetology and ichthyology of Nicaragua and Peru. Journal of the Academy of Natural Sciences of Philadelphia N.S. 8: 93-183.

Czaplewski NJ, Rincón AD, Morgan GS. 2005. Fossil Bat (Mammalia: Chiroptera) Remains from Inciarte Tar Pit, Sierra de Perijá, Venezuela. Caribbean Journal of Science 41:768-781.

860

861

862

863

864

865

866

867

868

869

870

871

872

873

Daudin FM. 1803. Histoire Naturelle, Générale et Particulière des Reptiles. F. Dufart, Paris, 439 pp.

Fortier DC, Rincón AD. 2013. Pleistocene crocodylians from Venezuela, and the description of a new species of Caiman. Quaternary Research 305: 141-148.

Friscia AR, Valkenburgh BV, Spencer L, Harris J. 2008. Chronology and spatial distribution of large mammal bones in Pit 91, Rancho La Brea. Palaios 23: 35-42.

Gray JE. 1842. Synopsis of the species of prehensile-tailed snakes, or family Boidae. Zoological Miscellany 2: 41-46.

Gray JE. 1849. Catalogue of the specimens of snakes in the collection of the British Museum. Edward Newman, London, i-xv; 125p.

875

876

877

878

879

880

881

882

Gray JE. 1860. Description of a new genus of Boidae discovered by Mr. Bates on the Upper Amazon. The Annals and magazine of natural history; zoology, botany, and geology 6: 131-132.

Gray JE. 1825. A synopsis of the genera of Reptilia and Amphibia. Annals of Philosophy 10: $193-217$.

884

885

Hackley PC, Urbani F, Karlsen AW, Garrity CP. 2006. Mapa Geologico de Venezuela a Escala 1:750,000. Available online at https://pubs.er.usgs.gov/publication/ofr20061109 (accessed 3 July 2017). 
Head JJ, Sanchéz-Villagra MR, Aguilera OA. 2006. Fossil snakes from the Neogene of Venezuela (Falcón State). Journal of Systematic Palaeontology 4: 233-240.

889

890

891

892

893

894

895

896

897

898

899

900

901

902

903

904

905

906

907

908

909

910

911

912

913

914

915

916

917

918

919

920

921

922

923

924

925

926

927

928

929

Head JJ, Mahlow K, Müller J. 2016. Fossil calibration dates for molecular phylogenetic analysis of snakes 2: Caenophidia, Colubroidea, Elapoidea, Colubridae. Palaeontologia Electronica 19.2.2FC: 1-21.

Henderson RW, Waller T, Micucci P, Puorto G, Bourgeois RW. 1995. Ecological correlates and patterns in the distribution of Neotropical Boines (Serpentes: Boidae): a preliminary assessment. Herpetological Natural History 3: 15-27.

Hoffstetter R, Gasc J. 1969. Vertebrate and ribs of modern reptiles. In:. C. Gans, A. D'A. Bellairs, and T. Parsons, (Eds), Biology of Reptilia. Academic Press, London, 201-310.

Hoffstetter R. 1967. Remarques sur les dates d' implantation des différents groupes de Serpents terrestres en Amérique du Sud. Comptes Rendues Sommaire des Séances de la Société Géologique de France 3: 93-94.

Hoffstetter R, Rage, JC. 1977. Le gisement de vertébrés miocènes de La Venta (Colombie) et sa faune de serpents. Annales de Paléontologie (Vertébrés) 63:161-190.

Hoge AR. 1953. A new genus and species of Boinae from Brazil, Xenoboa cropanii, gen. nov., sp. nov. Memórias do Instituto Butantan 25: 27-31.

Holanda EC, Rincón AD. 2012. Tapirs from the Pleistocene of Venezuela. Acta Palaeontologica Polonica 57: 463-473.

Holden AR, Erwin DM, Schick KN, Gross J. 2015. Late Pleistocene galls from the La Brea Tar Pits and their implications for cynipine wasp and native plant distribution in southern California. Quaternary Research 84: 358-367.

Holden AR, Southon JR, Will K, Kirby ME, Aalbu RL, Markey MJ. 2017. A 50,000 year insect record from Rancho La Brea, Southern California: Insights into past climate and fossil deposition. Quaternary Science Reviews 168: 123-136.

Holman JA. 1977. Upper Miocene Snakes (Reptilia, Serpentes) from Southeastern Nebraska. Journal of Herpetology 11: 323-335.

Holman JA. 2000. Fossil Snakes of North America. Indiana University Press, Bloomington, Indiana, $357 \mathrm{pp}$.

Hsiou AS, Albino AM, Ferigolo J. 2010. Reappraisal of the South American Miocene snakes of the genus Colombophis, with description of a new species. Acta Palaeontologica Polonica 55: 365-379. 
931 Hsiou AS, Albino AM. 2009. Presence of the genus Eunectes (Serpentes, Boidae) in

932

933

934

935

936

937

938

939

940

941

942

943

944

945

946

947

948

949

950

951

952

953

954

955

956

957

958

959

960

961

962

963

964

965

966

967

968

969

970

971

972

973

974

975

976

the Neogene of Southwestern Amazonia, Brazil. Journal of Herpetology 43: 612-619.

Hsiou AS, Albino AM. 2010. New snake remains from the Miocene of northern South America. Herpetological Journal 20: 249-259.

Hsiou AS, Albino AM, Medeiros MA, Santos RAB. 2014. The oldest Brazilian snakes from the Cenomanian (early Late Cretaceous). Acta Paleontologica Polonica 59: 635642.

Hsiou AS, Albino AM. 2011. First record of Viperidae snakes from the Pleistocene of southwestern Brazilian Amazonia. Alcheringa 35: 389-395.

Hsiou AS, Winck GR, Schubert BW, Ávilla L. 2013. On the presence of Eunectes murinus (Squamata, Serpentes) from the late Pleistocene of northern Brazil. Revista Brasileira de Paleontologia 16: 77-82.

Ituralde-Vinent MA, MacPhee RDE, Díaz-Franco S, Rojas-Consuegra R., Suárez W., Lomba A. 2000. Las Breas de San Felipe, a Quaternary fossiliferous asphalt seep near Martí (Matanzas Province, Cuba). Caribbean Journal of Science 36:300-313.

Ivanov M, Böhme M. 2011. Snakes from Griesbeckerzell (Langhian, Early Badenian), North Alpine Foreland Basin (Germany), with comments on the evolution of snake faunas in Central Europe during the Miocene Climatic Optimum. Geodiversitas 33: 411-449.

Jull AJT, Ituralde-Vinent M, O'Malley JM, MacPhee RDE, McDonald HG, Martin PS, Moody J, Rincón AD. 2004. Radiocarbon dating of extinct fauna in the Americas recovered from tar pits. Nuclear Instruments and Methods in Physics Research B 224: $668-671$.

Kluge AG. 1991. Boine snake phylogeny and research cycles. Miscellaneous publications (University of Michigan. Museum of Zoology) 178: 1-58.

LaDuke TC. 1991a. The fossil snakes of Pit 91, Rancho La Brea, California. Contributions in Science 424:1-28.

LaDuke TC. 1991b. Morphometric Variability of the Precaudal Vertebrae of Thamnophis sirtalis sirtalis (Serpentes: Colubridae), and Implications for the Interpretation of the Fossil Record. Ph.D. thesis, City University of New York, New York.

Lee MSY, Scanlon JD. 2002. Snake phylogeny based on osteology, soft anatomy and ecology. Biological Reviews of the Cambridge Philosophical Society 77: 333-401.

Lee MSY, Sanders KL, King B, Palci A. 2016. Diversification rates and phenotypic evolution in venomous snakes (Elapidae). Royal Society Open Science 3:150277. DOI: http://dx.doi.org/10.1098/rsos.150277. 
Linnaeus C. 1758. Systema naturae per regna tria naturae, secundum classes, ordines, genera, species, cum characteribus, differentiis, synonymis, locis. Laurentii Salvii,

980

981

982 Holmiae, 824 p.

McDonald GH, Moody JM, Rincón AD. 1999. Preliminary report on Pleistocene vertebrates from asphalt deposits in the Maracaibo basin, Venezuela. Congreso Internacional-Evolución Neotropical del Cenozoico, 19-22 May, La Paz-Bolivia. Programa y Resúmenes, p. 27.

Müller J. 1831. Beiträge zur Anatomie und Naturgeschichte der Amphibien. Zeitschrift für Physiologie 4: 190-275.

989

990

991

992

993

Nopcsa F. 1923. Eidolosaurus und Pachyophis, Zwei neue Neocom Reptilien. Palaeontographica 55: 97-154.

994

O'Dea A, Lessios HA, Coates AG, Eytan RI, Restrepo-Moreno SA, Cione AL, Collins 995

996

997

998

999

1000

1001

1002

1003

1004

1005

1006

1007

1008

1009

1010

1011

1012

1013

1014

1015

1016

1017

1018

1019

1020

1021 LS, De Queiroz A, Farris DW, Norris RD, Stallard RF, Woodburne MO, Aguilera O, Aubry MP, Berggren WA, Budd AF, Cozzuol MA, Coppard SE, Duque-Caro H, Finnegan S, Gasparini GM, Grossman EL, Johnson KG, Keigwin LD, Knowlton N, Leigh EG, Leonard-Pingel JS, Marko PB, Pyenson ND,, Rachello-Dolmen PG, Soibelzon E, Soibelzon L, Todd JA, Vermeji GJ, Jacson JBC. 2016. Formation of the Isthmus of Panama. Science Advances 2:e1600883. DOI: 10.1126/sciadv.1600883

Onary-Alves SY, Hsiou AS, Rincón AD. 2016. The northernmost South American fossil record of Boa constrictor (Boidae, Boinae) from Plio-Pleistocene of El Breal de Orocual (Venezuela). Alcheringa 41: 1-8.

DOI: http://dx.doi.org/10.1080/03115518.2016.1180031

Parmley D, Holman JA. 2003. Nebraskophis Holman from the late Eocene of Georgia (USA), the oldest known North American colubrid snake. Acta Zoologica Cracoviensia 46: 1-8.

Prevosti FJ, Rincón AD. 2007. A new fossil canid assemblage from the Late Pleistocene of northern South America: The canids of the Inciarte Asphalt Pit (Zulia, Venezuela), fossil record and biogeography. Journal of Paleontology 81: 1053-1065.

Pyron RA, Burbrink FT, Wiens JJ. 2013. A phylogeny and revised classification of Squamata, including 4161 species of lizards and snakes. BMC Evolutionary Biology 13: $1-53$.

Rage JC. 1984. Part 11 Serpentes. In: M. Wellnhofer, (Ed.), Encyclopedia of Paleoherpetology. Gustav Fischer Verlag, New York, USA, 1-79.

Rage JC. 2001. Fossil snakes from the Paleocene of São José de Itaboraí. Brazil. Part II. Boidae. Paleovertebrata 30: 111-150. 
1023 Rendahl H, Vestergren G. 1941. Notes on Colombian snakes. Arkiv för Zoologi 33A 1024 [1940] 5: 1-16.

1025

1026

1027

1028

1029

1030

1031

1032

1033

1034

1035

1036

1037

1038

1039

1040

1041

1042

1043

1044

1045

1046

1047

1048

1049

1050

1051

1052

1053

1054

1055

1056

1057

1058

1059

1060

1061

1062

1063

1064

1065

1066

1067

Rieppel O. 1988. A review of the origin of snakes. Evolutionary Biology 22: 37-130.

Rincón AD, White RS, McDonald G. 2008. Late Pleistocene cingulates (Mammalia: Xenarthra) from Mene de Inciarte tar pits, Sierra de Perijá, western Venezuela. Journal of Vertebrate Paleontology 28: 197-207.

Rincón AD. 2006. A first record of the Pleistocene saber-toothed cat Smilodon populator Lund, 1842 (Carnivora: Felidae: Machairodontinae) from Venezuela. Ameghiniana 43: 499-501.

Rincón AD. 2011. New remains of Mixotoxodon larensis Van Frank 1957 (Mammalia: Notoungulata) from Mene de Inciarte tar pit, North-Western Venezuela. Interciencia 36: 894-899.

Rincón AD, Prevosti FJ, Parra GE. 2011. New saber-toothed cat records (Felidae: Machairodontinae) for the Pleistocene of Venezuela, and the Great American Biotic Interchange. Journal of Vertebrate Paleontology 31: 468-478.

Rincón AD, Parra G, Prevosti FJ, Alberdi MT. Bell CJ. 2009. A preliminary assessment of the mammalian fauna from the Pliocene-Pleistocene El Breal de Orocual locality, Monaga State, Venezuela. In: B. Albright (Ed.) Papers on Geology, Vertebrate Paleontology and Biostratigraphy, in honor of Mike O. Woodburne, Bulletin of the Museum of Northern Arizona 65: 593-620.

Rincón AD, Alberdi MT, Prado JL. 2006. Nuevo registro de Equus (Amerhippus) santaeelenae (Mammalia, Perissodactyla) del pozo de asfalto de Inciarte (Pleistoceno Superior), estado Zulia, Venezuela. Ameghiniana 43:529-538.

Rincón AD, Parra GE, Prevosti FJ, Alberdi MT, Bell CJ. 2009. A preliminary assessment of the mammalian fauna from the Pliocene-Pleistocene El Breal de Orocual locality, Monagas State, Venezuela. In: L.B. Albright, (Ed.) Papers on Geology, Vertebrate Paleontology, and Biostratigraphy in Honor of Michael O. Woodburne. Museum of Northern Arizona Bulletin 64: 593-620.

Rivas GA, Molina CR, Ugueto GN, Barros TR, Barrioamorós CL, Kok PJR. 2012. Reptiles of Venezuela: an updated and commented checklist. Zootaxa 3111: 1-64.

Riveira PC, Di Cola V, Martinéz JJ, Gardenal CN, Chiaraviglio M. 2011. Species Delimitation in the Continental Forms of the Genus Epicrates (Serpentes, Boidae) Integrating Phylogenetics and Environmental Niche Models. PLoS ONE 6:e22199.

1068

Rodrigues MT. 2005. The Conservation of Brazilian Reptiles: Challenges for a Megadiverse Country. Conservation Biology 19: 659-664. 
1069

1070

1071

1072

1073

1074

1075

1076

1077

1078

1079

1080

1081

1082

1083

1084

1085

1086

1087

1088

1089

1090

1091

1092

1093

1094

1095

1096

1097

1098

1099

1100

1101

1102

1103

1104

1105

1106

1107

1108

1109

1110

1111

1112

1113

Scotese C.R. 2010. PALEOMAP Project. Avaliable at

http://www.scotese.com/Default.htm

Solórzano A, Rincón AD, McDonald HG. 2015. A new mammal assemblage from the Late Pleistocene El Breal de Orocual, northeast of Venezuela. In: J.M. Harris (Ed.), La Brea and Beyond: The Paleontology of Asphalt-Preserved Biotas. Science Series, Natural History Museum of Los Angeles County 42: 125-150.

Steadman DW, Oswald JA, Rincón AD. 2015. The diversity and biogeography of late Pleistocene birds from the lowland Neotropics. Quaternary Research 83: 555-564.

Szyndlar Z, Rage JC. 2003. Non-erycine Booidea from the Oligocene and Miocene of Europe. Institute of Systematics and Evolution of Animals, Polish Academy of Science, Kraków, Poland, 109 pp.

Teixeira G. 2013. Anatomia comparada dos Boinae (Serpentes, Boidae) sul-americanos: uma abordagem osteológica para fins aplicativos na paleontologia de vertebrados. Monograph, Universidade de São Paulo, Ribeirão Preto, 88 p.

Uetz P, Hošek J. 2016. The reptile database. Available online at: http://reptiledatabase.reptarium.cz/ (accessed 7 August 2017).

Underwood GL, Kochva E. 1993. On the affinities of the burrowing asps Atractaspis (Serpentes: Atractaspididae). Zoological Journal of the Linnean Society 107: 3-64.

Urbani F, Galarraga F. 1991. Inventario de menes de la Sierra de Perijá. Univ. Central Venezuela. Facult. Ingeniería. Esc. Geol., Minas y Geofís. Informe interno 1-80.

Venczel M. 2001. Anurans and squamates from the Lower Pliocene (MN 14) Osztramos 1 locality (Northern Hungary). Fragmenta Palaeontologica Hungarica 19: 79-90.

Verzi DH, Deschamps CM, Montalvo CL. 2004. Bioestratigrafía y biocronología del Mioceno Tardío en Argentina central. Ameghiniana 41(4, Suplemento):21R.

Ward JK, Harris JM, Cerling TE, Wiedenhoeft A, Lott MJ, Dearing MD, Coltrain JB, Ehleringer JR. 2005. Carbon starvation in glacial trees recovered from La Brea tar pits, southern California. Proceedings of the National Academy of Sciences of the United States of America 102: 690-694.

Wüster W, Ferguson JE, Quijada-Mascareñas JA, Pook CE, Salomão MG, Thorpe RS. 2005. Tracing an invasion: landbridges, refugia, and the phylogeography of the Neotropical rattlesnake (Serpentes: Viperidae: Crotalus durissus). Molecular Ecology 14: 1095-1108. 
1114 Wüster W, Salomão MG, Quijada-Mascareñas JA, Thorpe RS, B.B.B.S.P. 2002. 1115 Origins and evolution of the South American pitviper fauna: evidence from mitochondrial 1116 DNA sequence analysis. In: G. W. Schuett, M. Höggren, M. E. Douglas, and H. W. Greene 1117 (Eds.). Biology of the Vipers. Eagle Mountain Publishing, Eagle Mountain, Utah, 1111118128.

Zaher H. 1999. Hemipenial morphology of the South American xenodontine snakes, with 1121 a proposal for a monophyletic Xenodontinae and a reappraisal of colubroid hemipenes. Bulletin of the American Museum of Natural History 240: 1-168.

Zaher H, Grazziotin FG, Cadle JE, Murphy RW, Moura-Leite JC. Bonatto SL. 2009. Molecular phylogeny of advanced snakes (Serpentes, Caenophidia) with an emphasis on South American xenodontines: a revised classification and descriptions of new taxa. Papéis Avulsos de Zoologia, Museu de Zoologia da Universidade de São Paulo 49:1151129 153. 


\section{Table $\mathbf{1}$ (on next page)}

Table of the comparative specimens consulted.

Museum abbreviations are given in the institutional abbreviations section. 


\begin{tabular}{|c|c|c|}
\hline Taxon & Group & $\begin{array}{c}\text { Museum and specimen } \\
\text { number }\end{array}$ \\
\hline Boa constrictor imperator & Boidae & $\begin{array}{c}\text { AMNH R } 155261, \text { AMNH R } \\
\text { 155257, AMNH R 77590, } \\
\text { AMNH R 74737, AMNH R } \\
57472\end{array}$ \\
\hline Boa constrictor & Boidae & $\begin{array}{c}\text { AMNH R 57467, AMNH R } \\
57476, \text { AMNH R 131475, } \\
\text { AMNH R 75478, AMNH R } \\
\text { 141144, AMNH R 7204, } \\
\text { AMNH R 75267, AMNH R } \\
\text { 7118, MCN.D, 333, MCN.D } \\
\text { 335, MCN.D 343, MCN.D } \\
\text { 344, MCN.D 347, MCN.D } \\
\text { 351 }\end{array}$ \\
\hline Corallus caninus & Boidae & $\begin{array}{c}\text { AMNH R 57788, AMNH R } \\
\text { 73347, AMNH R 57816, } \\
\text { AMNH R 155265, AMNH R } \\
\text { 169154, AMNH R 155260, } \\
\text { AMNH R 73347, AMNH R } \\
\text { 155264, AMNH R 139338, } \\
\text { AMNH R 155263, AMNH R } \\
57816\end{array}$ \\
\hline Crotallus durissus & Viperidae & $\begin{array}{c}\text { AMNH 56455, AMNH } \\
744442\end{array}$ \\
\hline Crotallus durissus terrificus & Viperidae & AMNH 77027 \\
\hline Clelia clelia & Colubroidea & AMNH 57797 \\
\hline Bothrops atrox & Viperidae & AMNH 29885 \\
\hline Bothrops bilineatus & Viperidae & AMNH R 140856 \\
\hline Corallus cf. C. caninus & Boidae & AMNH R 57804 \\
\hline Corallus annulatus & Boidae & AMNH R 114496 \\
\hline Corallus batesi & Boidae & UFMT-R 05362 \\
\hline Drymarchon corais couperi & Colubroidea & AMNH R 155299 \\
\hline Eunectes murinus & Boidae & $\begin{array}{c}\text { AMNH 57474, MCN.D 306, } \\
\text { MCN.D 316, MCN.D 319, } \\
\text { MCN.D } 342\end{array}$ \\
\hline Epicrates crassus & Boidae & MCN-PV DR 0003 \\
\hline Epicrates striatus & Boidae & AMNH R 140542 \\
\hline Epicrates striatus striatus & Boidae & AMNH R 155262 \\
\hline $\begin{array}{l}\text { Epicrates striatus } \\
\text { strigilatus }\end{array}$ & Boidae & $\begin{array}{l}\text { AMNH 155259, AMNH R } \\
\text { 70263, AMNH R } 155259\end{array}$ \\
\hline Epicrates striatus fosteri & Boidae & $\begin{array}{l}\text { AMNH R 77633, AMNH R } \\
77057\end{array}$ \\
\hline Corallus cropanii & Boidae & AMNH R 92997 \\
\hline Corallus hortulanus cookii & Boidae & $\begin{array}{c}\text { AMNH R 141098, AMNH R } \\
\text { 74832, AMNH R 7812, }\end{array}$ \\
\hline
\end{tabular}




\begin{tabular}{|c|c|c|}
\hline & & $\begin{array}{l}\text { AMNH R 75740, AMNH R } \\
57809\end{array}$ \\
\hline Corallus hortulanus & Boidae & $\begin{array}{l}\text { AMNH 104528, AMNH R } \\
\text { 57786, MCN-PV DR 0001, } \\
\text { UFMT 02389, UFMT 02398 }\end{array}$ \\
\hline Chironius carinatus & Colubroidea & AMNH 82841 \\
\hline Dipsas indica & Colubroidea & AMNH 53780 \\
\hline Drymoluber dichrous & Colubroidea & AMNH 55847 \\
\hline Dendrophidian nucale & Colubroidea & AMNH 138461 \\
\hline $\begin{array}{l}\text { Erythrolamprus mimus } \\
\text { micrurus }\end{array}$ & Colubroidea & AMNH 109828 \\
\hline Erythrolamprus bizona & Colubroidea & AMNH 90018 \\
\hline Epicrates angulifer & Boidae & $\begin{array}{c}\text { AMNH R 77596, AMNH R } \\
114497\end{array}$ \\
\hline Epicrates cenchria & Boidae & $\begin{array}{c}\text { AMNH R 114716, AMNH R } \\
\text { 57473, AMNH R 71153, } \\
\text { AMNH R 75796, AMNH R } \\
\text { 75795, MCN-PV DR } 0002\end{array}$ \\
\hline Epicrates inornatus & Boidae & AMNH 70023 \\
\hline Helicops angulatus & Colubroidea & $\begin{array}{c}\text { AMNH R 139137, AMNH R } \\
\text { 155310, AMNH R } 56031\end{array}$ \\
\hline Hydrodynastes bicinctus & Colubroidea & AMNH 60822 \\
\hline Hydrodynastes gigas & Colubroidea & AMNH 57956 \\
\hline $\begin{array}{l}\text { Mastigodryas boddaerti } \\
\text { boddaerti }\end{array}$ & Colubroidea & AMNH R 8675 \\
\hline Micrurus spixi obscurus & Elapidae & AMNH 74813 \\
\hline $\begin{array}{c}\text { Micrurus lemniscatus } \\
\text { diutius }\end{array}$ & Elapidae & AMNH 78969 \\
\hline Pseustes poecilonotus & Colubroidea & AMNH 85309 \\
\hline Ninia atrata & Colubroidea & AMNH R 75825 \\
\hline Oxybelis aeneus & Colubroidea & AMNH R 155359 \\
\hline Oxyrhopus petola & Colubroidea & AMNH 77649 \\
\hline Oxyrhopus trigeminus & Colubroidea & AMNH 85969 \\
\hline Urotheca multilineata & Colubroidea & AMNH R 98288 \\
\hline Spillotes pullatus & Colubroidea & AMNH R-155390 \\
\hline Xenodon rhabdocephalus & Colubroidea & AMNH 70257 \\
\hline Xenodon severus & Colubroidea & $\begin{array}{l}\text { AMNH 35997, AMNH R } \\
76573\end{array}$ \\
\hline
\end{tabular}

2 Table 1: Table of the comparative specimens consulted. Museum abbreviations are given

3 in the institutional abbreviations section. 
Figure 1

Geographical map of Venezuela showing the relative position of the deposits where the snake remains were found

El Breal de Orocual (Plio/ Pleistocene), in pink dot, and Mene de Inciarte (upper Pleistocene) in red pentagon. (Map drawing by Ascanio Rincón and minor edits by Silvio Onary).

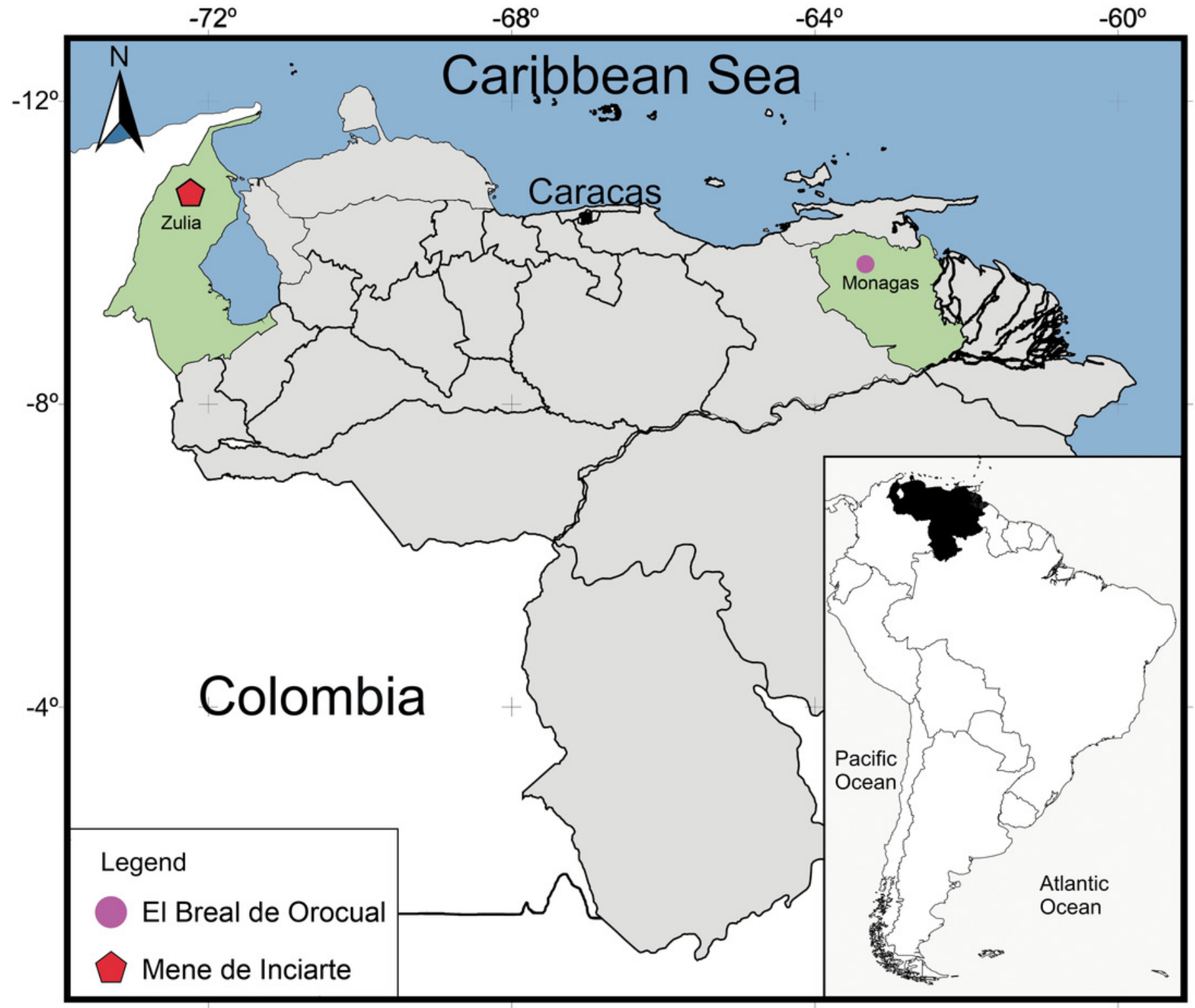




\section{Figure 2}

Isolated midtrunk vertebra of Boa constrictor evidencing the anatomical traits and quantitative data here analysed

A. Isolated midtrunk vertebra of Boa constrictor (MCN.D. 344) showing the anatomical nomenclature herein adopted. B. same vertebra evidencing the quantitative measurements adopted in this study. Based in LaDuke (1991a,b). In (1) anterior, (2) posterior, (3) dorsal, (4) ventral, and (5) lateral views. Scale bar: $10 \mathrm{~mm}$. Abbreviations: azs, articular facet of zygosphene; $\mathrm{cl}$, centrum length; $\mathrm{cn}$, condyle; coh, condyle height; cow, condyle width; ct, cotyle; cth, cotyle height; ctw, cotyle width; di, diapophysis; $h$, total height of vertebra; hk, haemal keel; ir, interzygapophyseal ridge; If, lateral foramen; naw, neural arch width; nc, neural canal; nch, neural canal height; ncw, neural canal width; ns, neural spine; nsl, neural spine length; par, parapophysis; pfo, paracotylar foramen; po-po, distance between postzygapophyses; ppz, parapophyseal process; prdp, paradiapophysis; prl, prezygapophysis length; pr-po, distance between prezygapophyses and postzygapophyses of the same side; pr-pr, pr-pr, distance between prezygapophyses; prw, prezygapophysis width; ptz, postzygapophisis; pz, prezygapophysis; sf, subcentral foramen; zgf, zygantral foramen; zh, zygosphene height; zw, zygosphene width. (Photography source: Silvio Onary) 
A

(1)

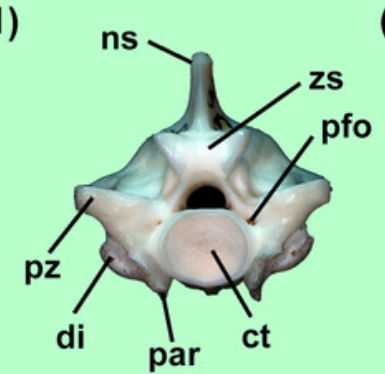

(3)

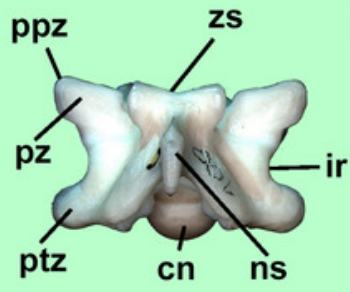

(5)

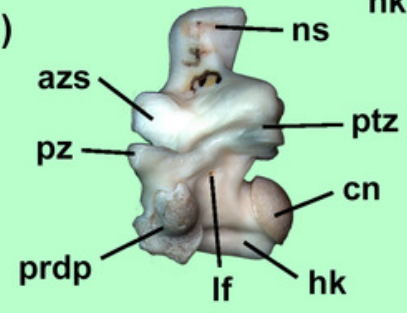

(4)
B

(1)
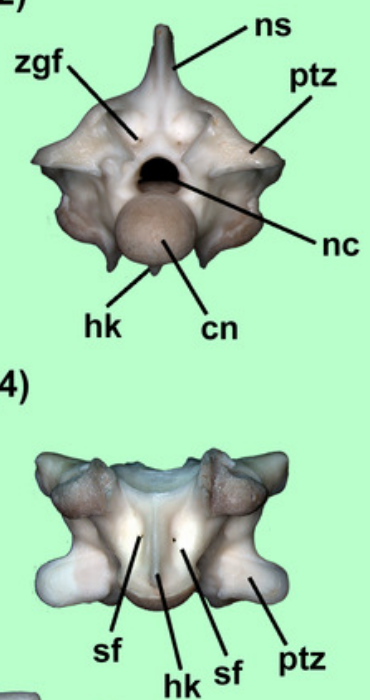

(3)

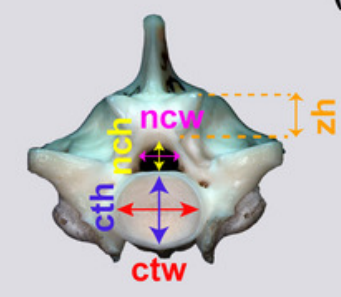

(2)

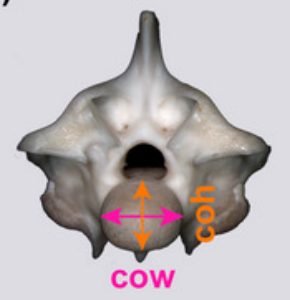

(4)
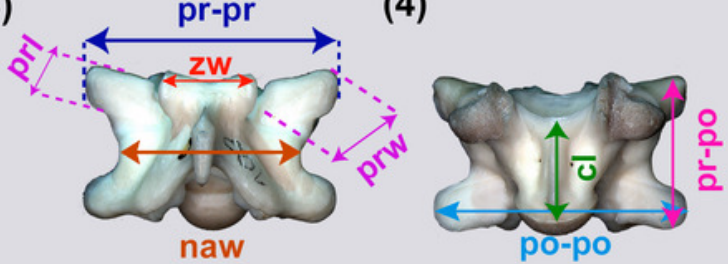

(5)

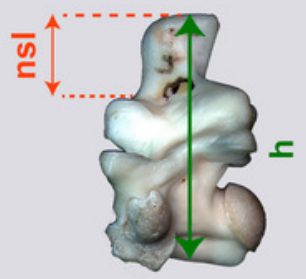


Figure 3

Fossil specimen IVIC OR-6113

A. Isolated posterior precloacal vertebra attributed to Corallus sp. (IVIC OR-6113). B.

Schematic drawing of the specimen evidencing its anatomical structures. In (1) anterior, (2) posterior, (3) lateral, (4) ventral, and (5) dorsal views. Abbreviations in figure 2. (Photography and outline drawing source: Silvio Onary)
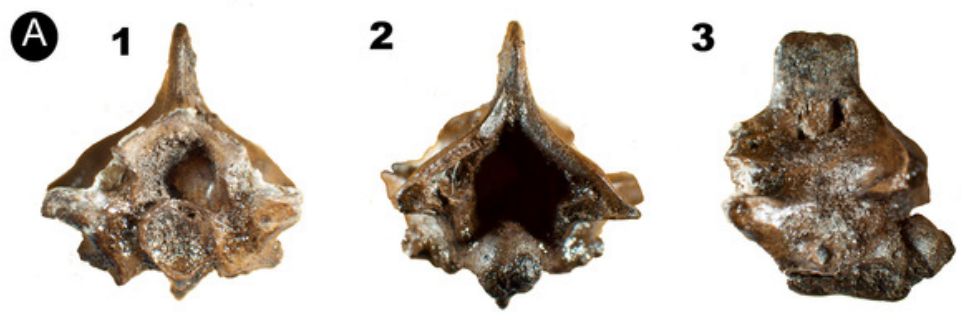

$2 \mathrm{~mm}$

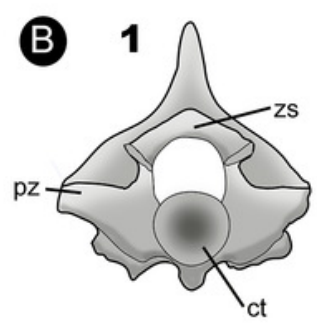

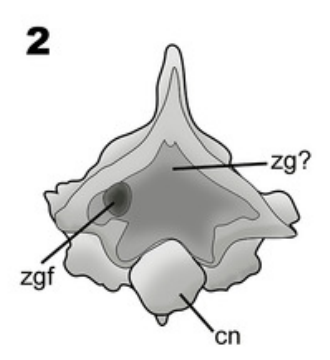

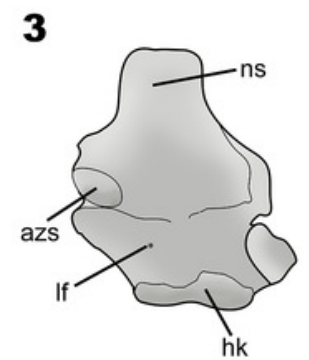

4

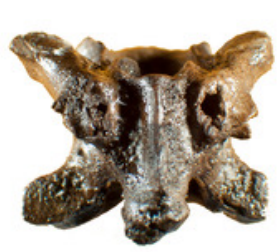

4

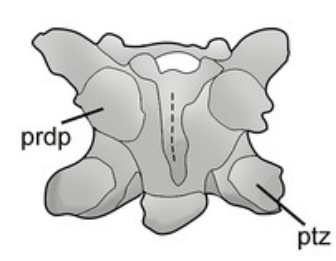

5

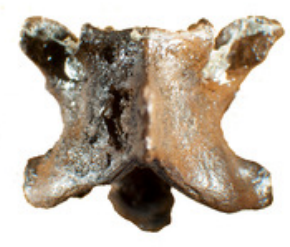

$2 \mathrm{~mm}$

5

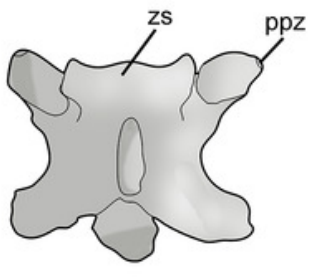




\section{Figure 4}

Fossil specimen of IVIC MI-004

A. Anterior precloacal vertebra attributed to Epicrates sp. (IVIC MI-004). B. Schematic drawing of the specimen evidencing the anatomical structures. Abbreviations in the relevant section. In (1) anterior, (2) posterior, (3) lateral, (4) ventral, and (5) dorsal views. Abbreviations in figure 2. (Photography and outline drawing source: Silvio Onary)

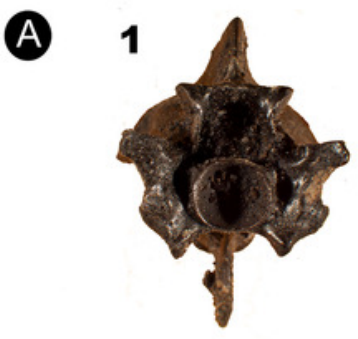

B

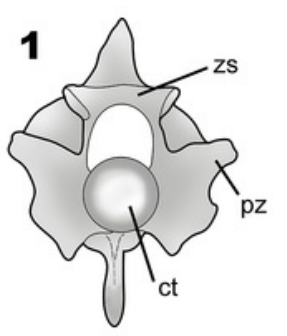

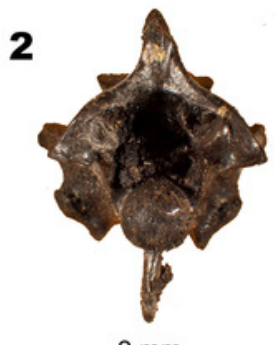

$2 \mathrm{~mm}$

2

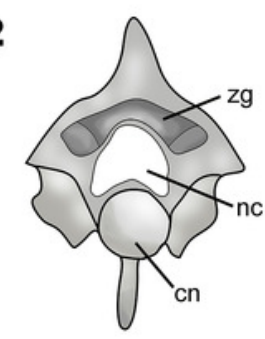

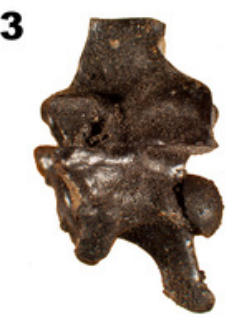

3

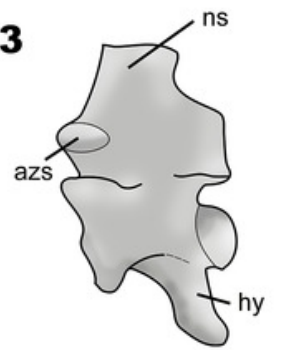

4

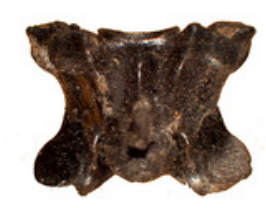

$2 \mathrm{~mm}$

4

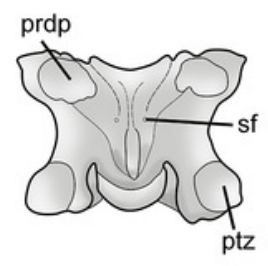

5

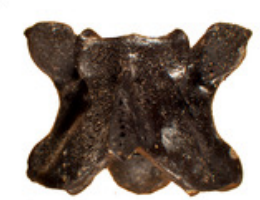

5

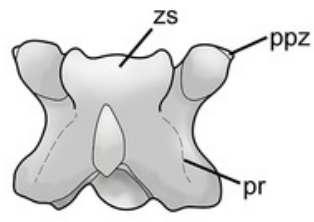


Figure 5

Isolated vertebral remains attributed to Colubroidea.

A. IVIC OR-3667; B. IVIC OR-6124; C. IVIC OR-2618; D. IVIC MI-005; and E. IVIC OR-2917. Abbreviations: hae, haemapophysis; pl, pleurapophysis. (Photography source: Silvio Onary) 

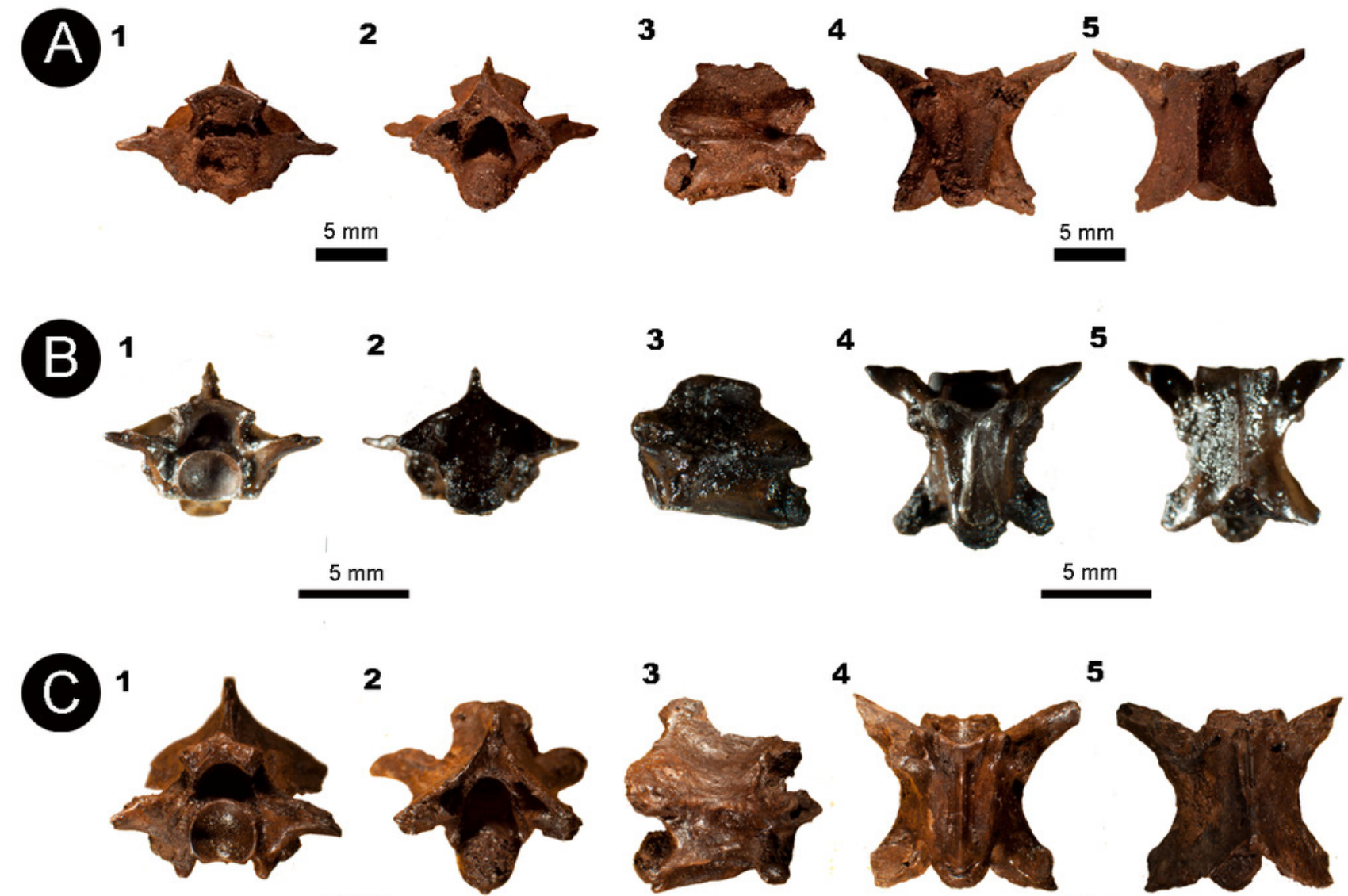

$10 \mathrm{~mm}$
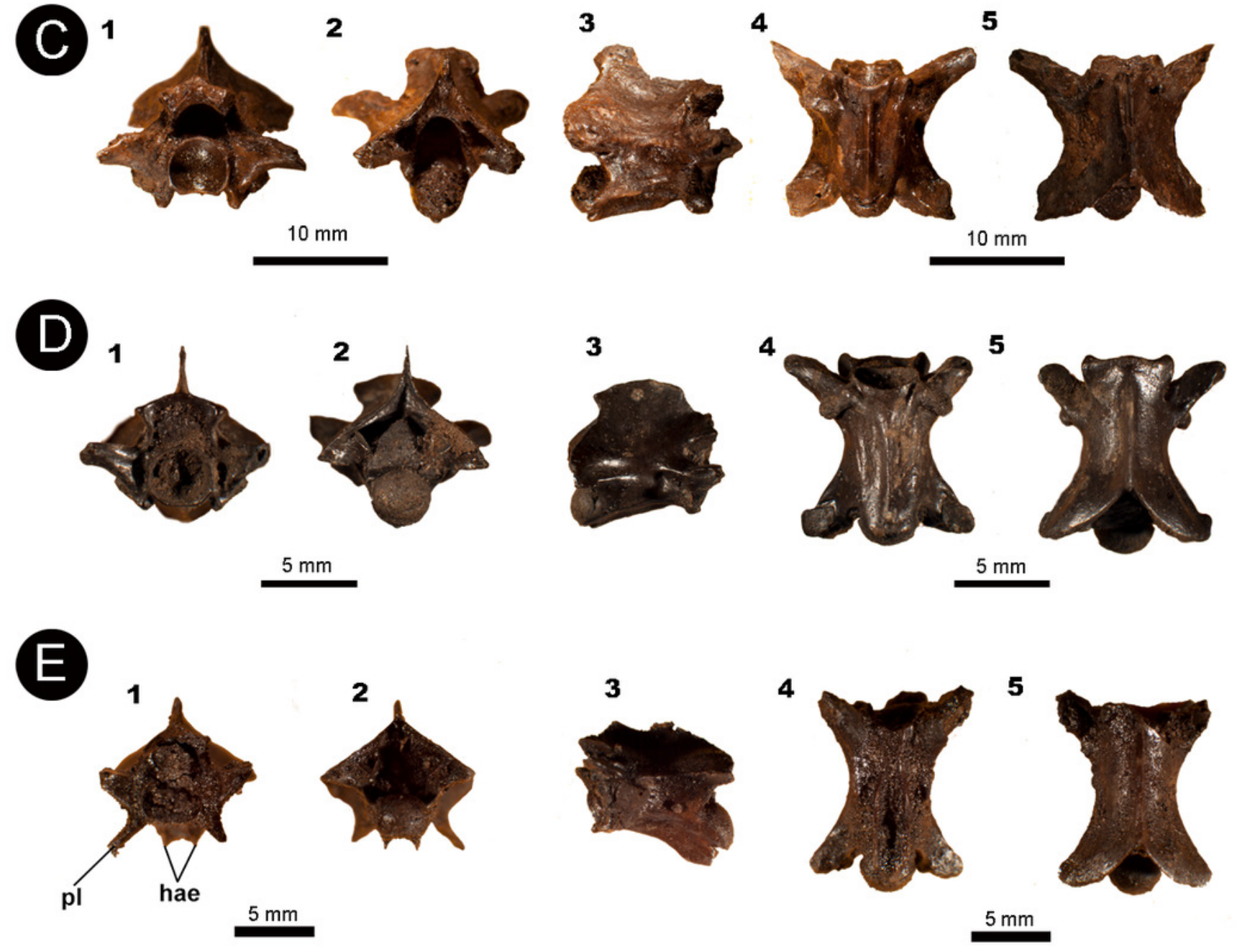


\section{Figure 6}

Isolated vertebral remains attributed to Viperidae.

A. IVIC OR-2617; B. schematic drawing of IVIC OR-2617; C. IVIC OR-6104; D. schematic drawing of IVIC OR-6104; E. IVIC OR-1760; F. schematic drawing of IVIC OR-1760. Abbreviations present in figure 2. (Photography and outline drawing source: Silvio Onary) 

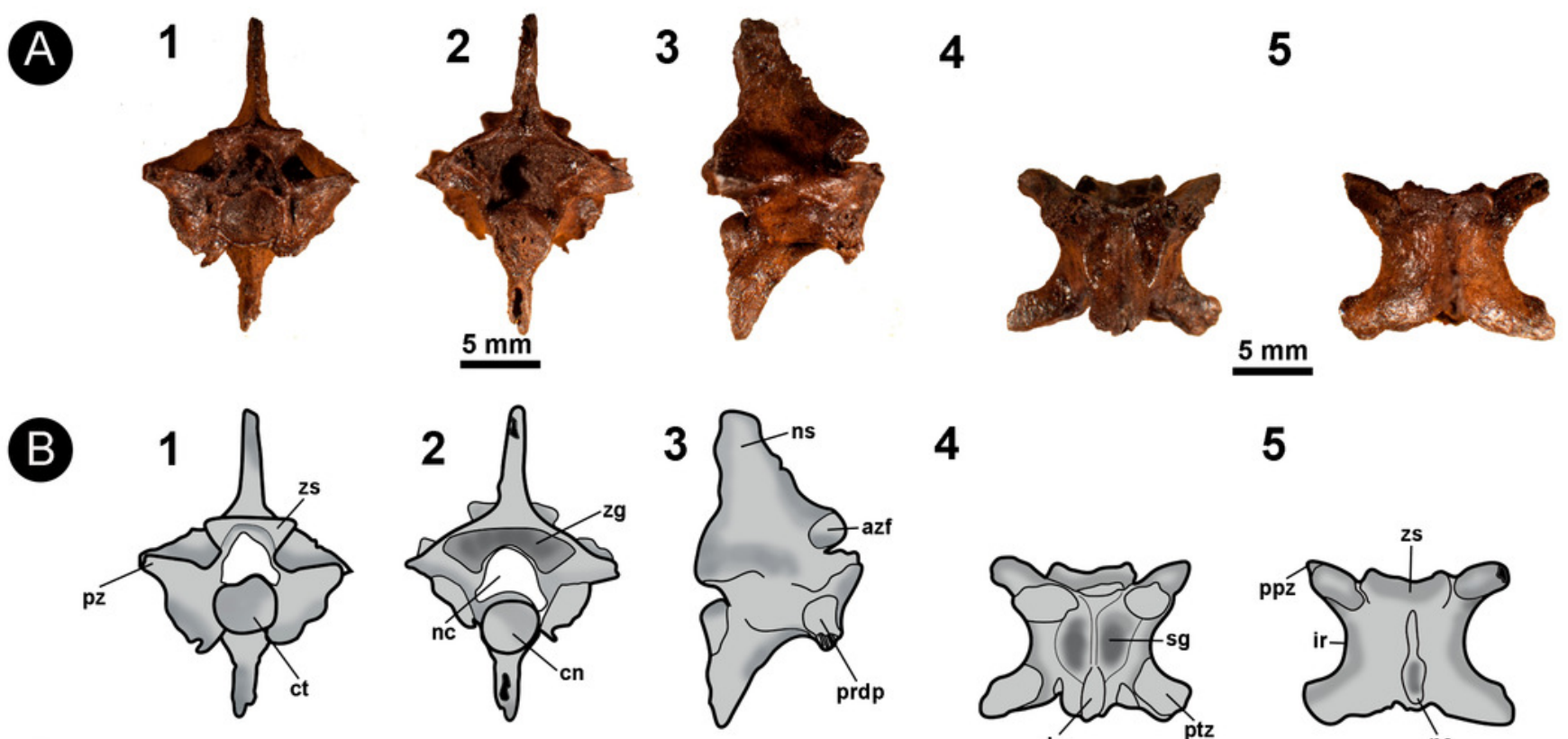

4

5
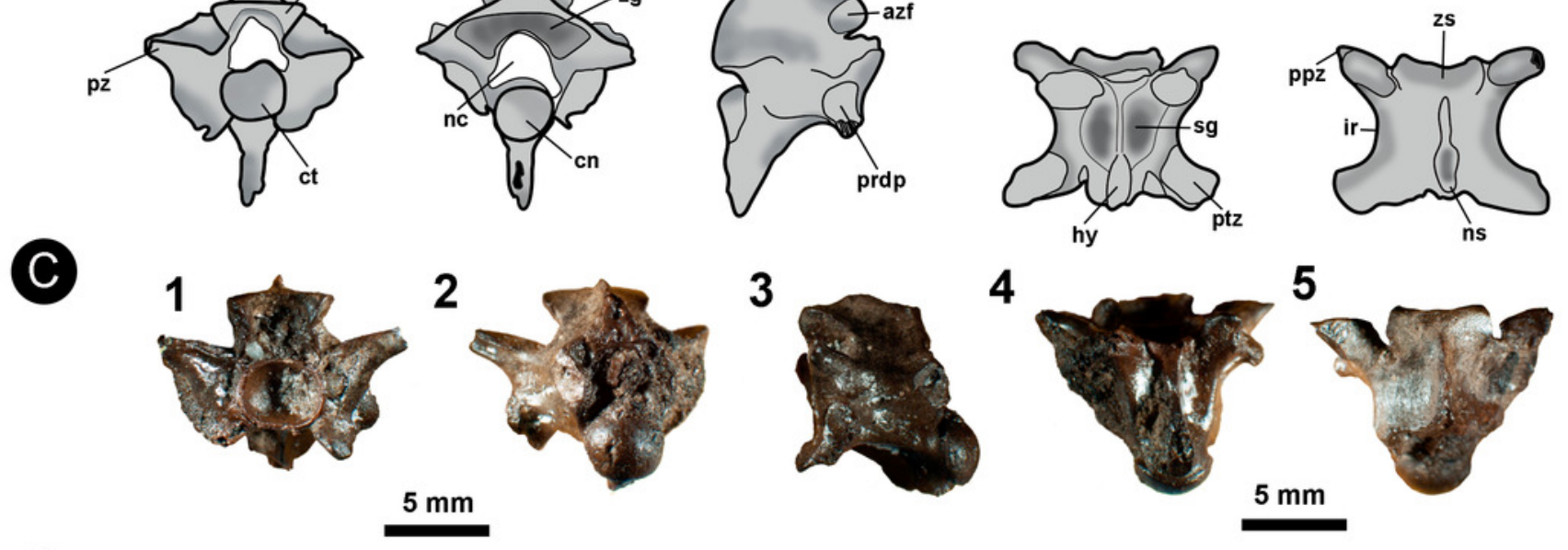

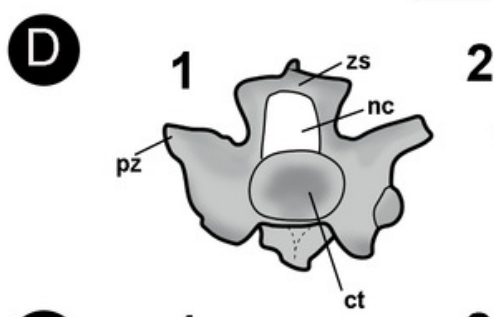

E

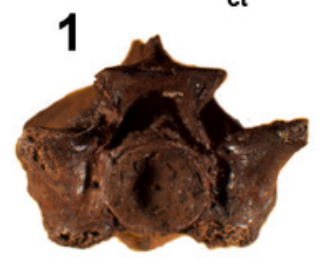

2
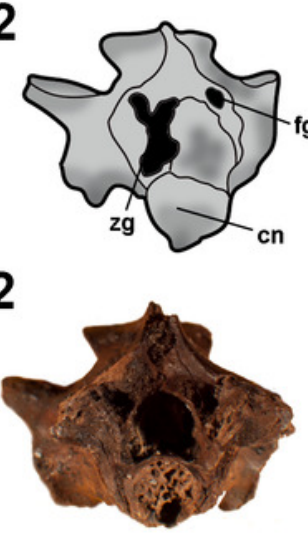

$5 \mathrm{~mm}$
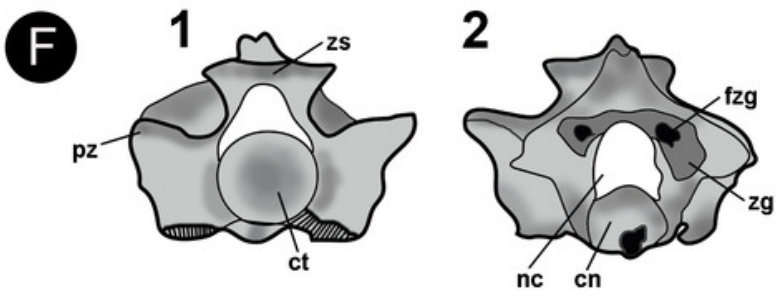
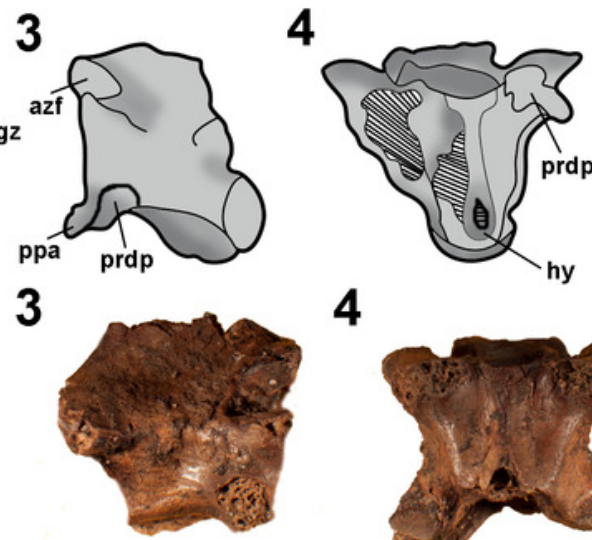

4

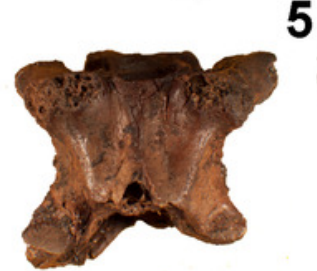

$5 \mathrm{~mm}$

5
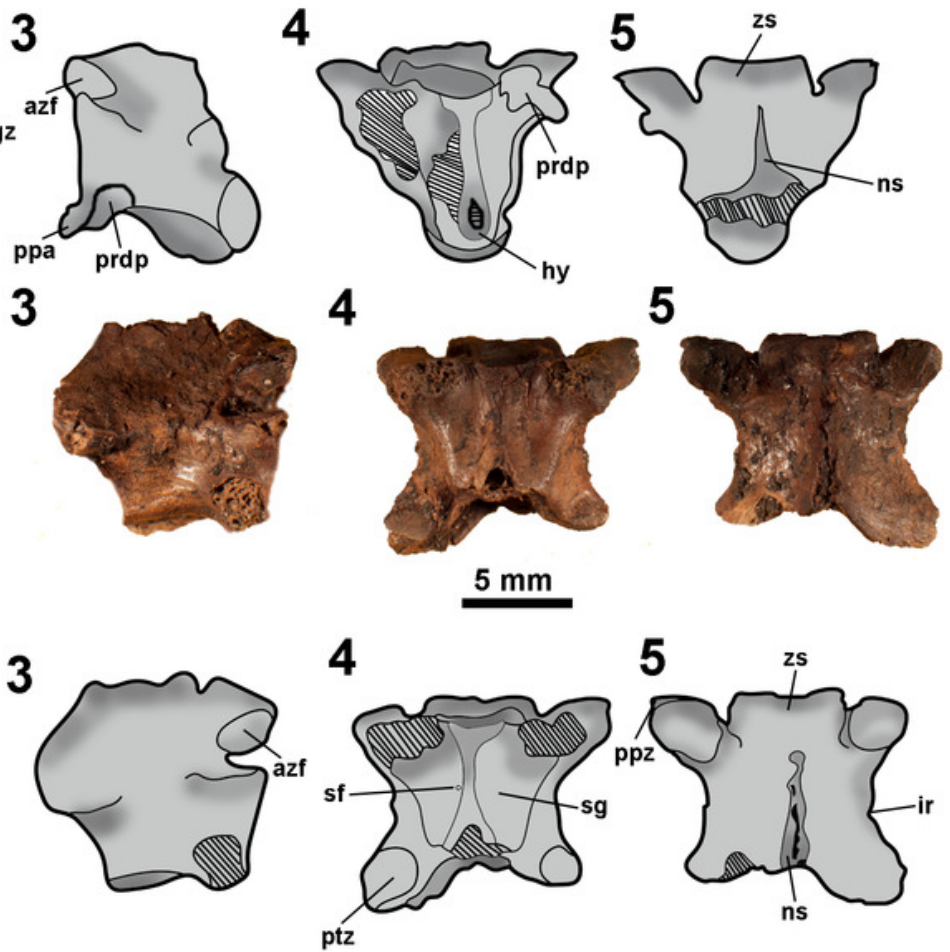


\section{Figure 7}

Fossil specimen of IVIC OR-2619

Isolated precloacal vertebra (IVIC OR-2619) identified as cf. Micrurus. B. schematic drawing of IVIC OR-2619; C. comparative material of precloacal vertebra of Micrurus lemniscatus diutius (AMNH 78969). Abbreviations in figure 2. (Photography and outline drawing source: Silvio Onary) 
A 1
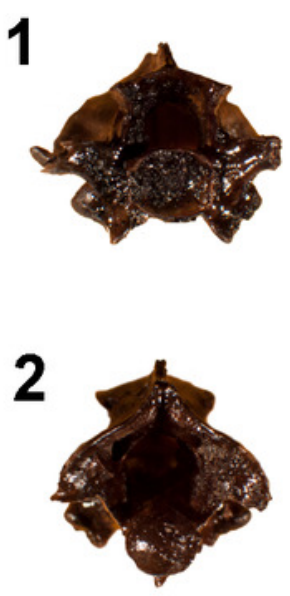

\section{$5 \mathrm{~mm}$}

3

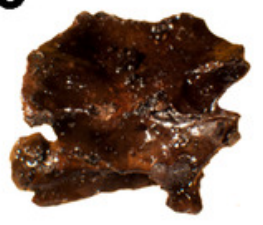

4

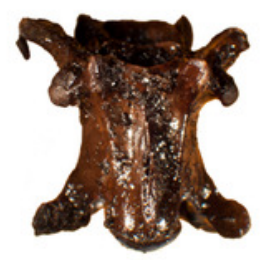

$5 \mathrm{~mm}$

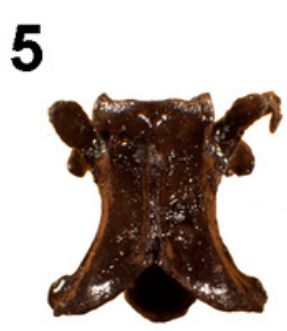

B
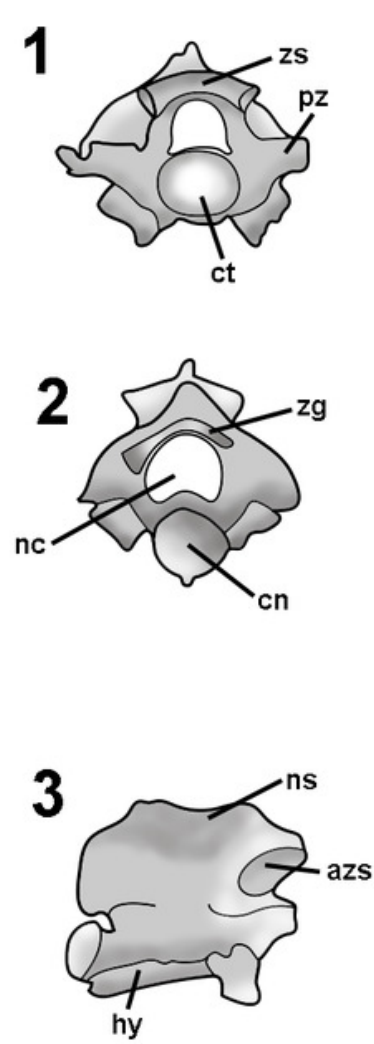

4

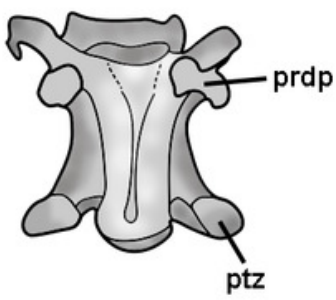

5

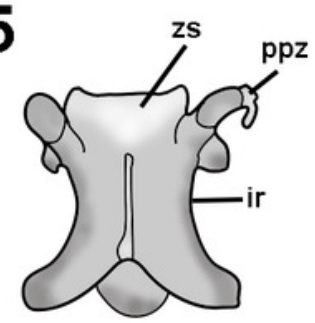

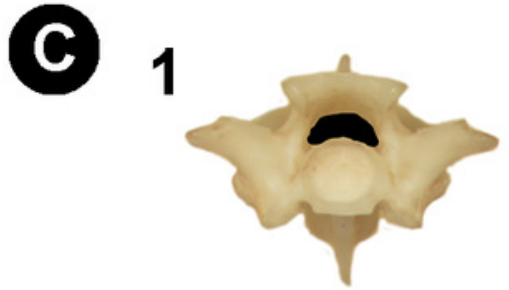

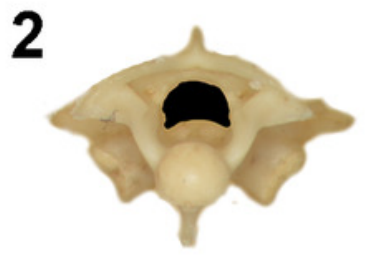

$5 \mathrm{~mm}$

3

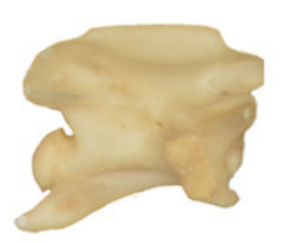

4

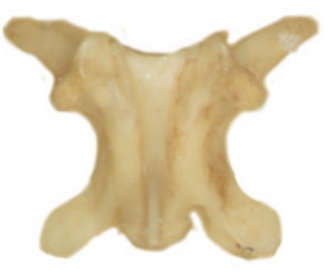

$5 \mathrm{~mm}$

5

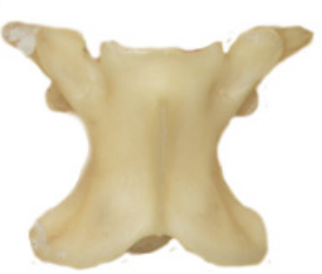




\section{Figure 8}

The historical biogeography of Colubroides (sensu Zaher et al. 2009) throughout the American continent during the Eocene to Pleistocene, based on the fossil record. (A) representative maps of Eocene; (B) Miocene; and (C) Pleistocene of America.

(1) The oldest American "Colubridae" recorded from the late Eocene of Georgia, North America (Parmley \& Holman, 2003); (2) "Colubridae" record from the early Miocene of Argentina, South America (Colhuehuiapianense South America Land Mammal Age, SALMA) (Albino, 1996b); (3) Viperidae remains from the late Miocene of Cerro Azul Formation (Huayquerian SALMA), Argentina (Albino \& Montalvo, 2006) and the "Colubridae" record from the late Miocene of Amazonia, Brazil (Hsiou \& Albino, 2010); (4) First entrance of Colubroides from North America to South America by dispersion via Central American island complex during the Miocene (Hoffstetter, 1967; Cadle \& Greene, 1993; Albino, 1996b); (5) Second event of dispersion of Colubroides from North America to South America during the Plio/Pleistocene (Head, Sánchez-Villagra \& Aguilera, 2006); (6) Viperidae remains from Cucuruchu gravels, late Pleistocene of Venezuela (Head, Sánchez-Villagra \& Aguilera, 2006); and (7) The herein described record of cf. Micrurus (Elapoidea, Elapidae), which is the putative oldest South American record of Elapidae, supporting the hypothesis of establishment of the genus in the South American continent at least 2.1 Ma, after the complete uplift of the Panama Isthmus (Rage \& Holman, 1984). Red arrows denote the first episode of dispersion and pink arrow denote the second event of dispersion. Palaeomaps based in the reconstructions from PALEOMAP Project (Scotese 2010). (Drawing designed by Silvio Onary) 

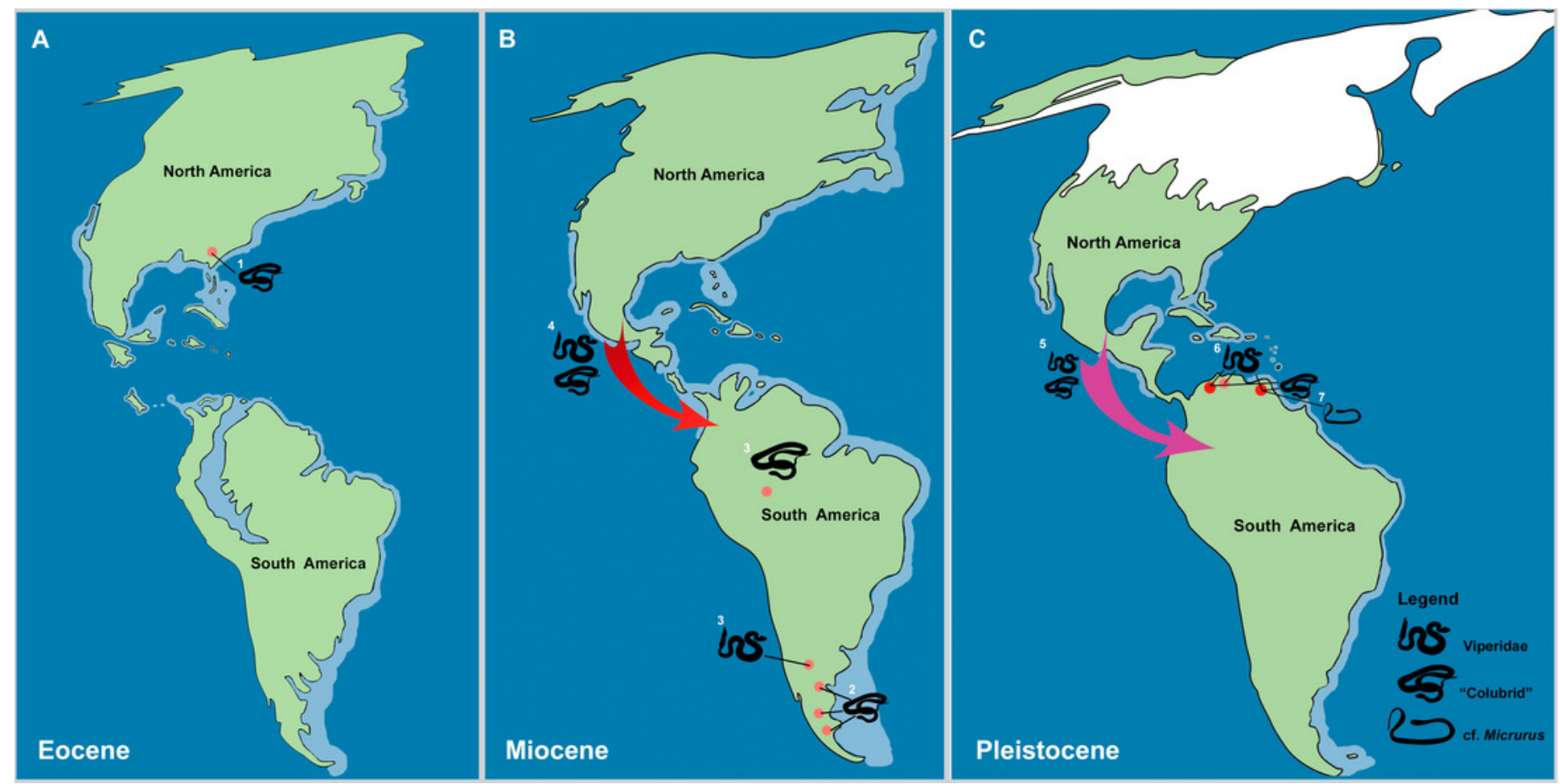